\title{
Stem Cells in Ophthalmology
}

\author{
Sara T. Wester ${ }^{1}$ and Jeffrey Goldberg ${ }^{1,2}$ \\ ${ }^{1}$ Department of Ophthalmology, Bascom Palmer Eye Institute \\ 2Interdisciplinary Stem Cell Institute \\ University of Miami Miller School of Medicine, Miami, Florida \\ USA
}

\section{Introduction}

Stem cell research in the field of ophthalmology over the past two decades has advanced knowledge and treatment dramatically. Stem cells are functionally defined as (a) cells that can self-renew and provide ongoing populations of identical daughter cells with the same

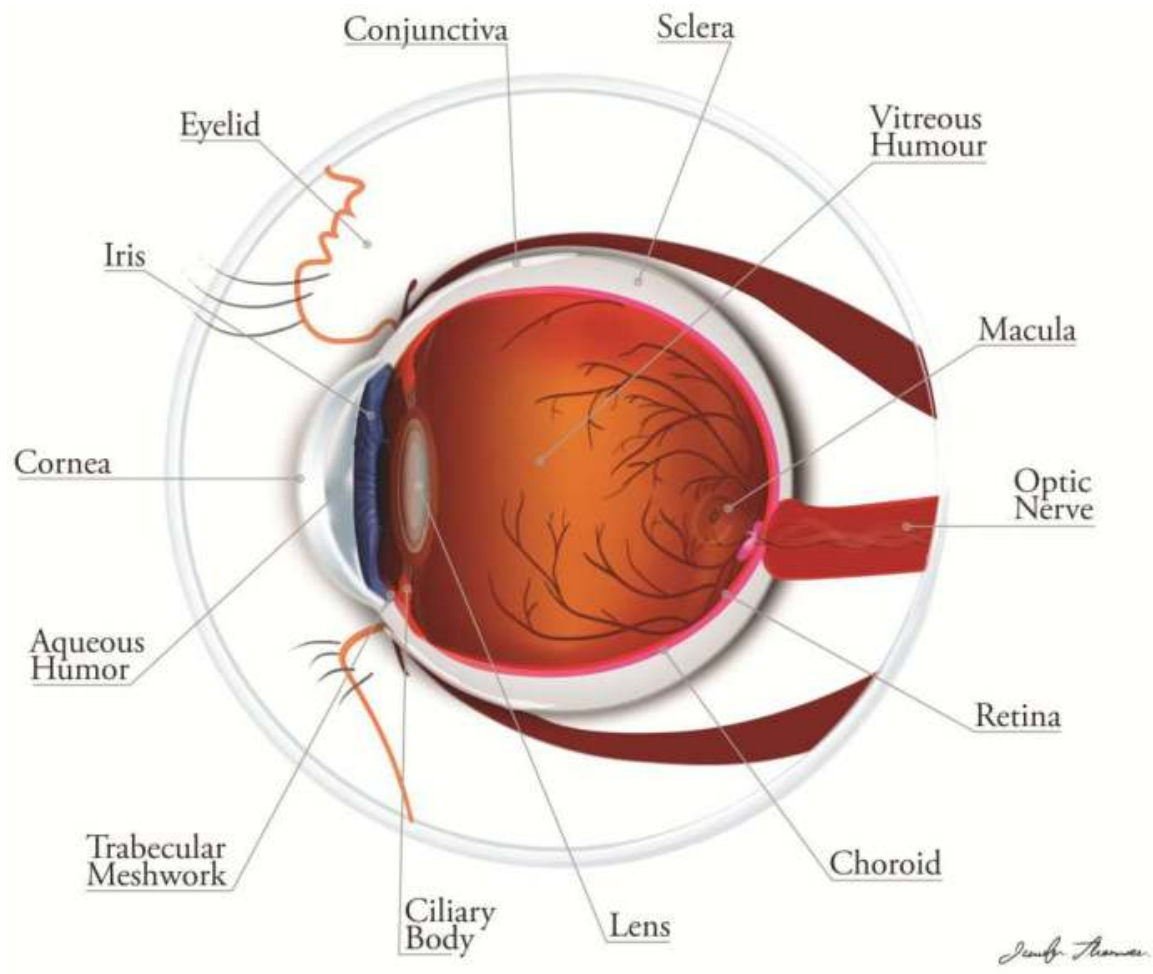

Fig. 1. Anatomy of the Eye and Extraocular Tissues (Illustration by Jennifer Thomson Ph D., Bascom Palmer Eye Institute, University of Miami Miller School of Medicine) 
unrestricted proliferation potential and (b) cells that are multipotent and able to give rise to all cell lineages in a particular tissue. Stem cells repopulate damaged or lost tissue either through differentiation into tissue appropriate cells and /or by releasing paracrine signaling molecules to recruit inflammatory cells and other tissue progenitor cells. As such, these cells have a key role in therapeutic tissue regeneration (Lau, 2009). From the establishment of the location of corneal epithelial stems cells to promising developments in diagnosis and treatment of ophthalmic diseases, an enhanced understanding of stem cells in ophthalmology offers promising diagnostic and therapeutic advances.

The purpose of this chapter is to outline our current knowledge and recent advances in stem cell research in ophthalmology. We will focus on the potential clinical applications of stem cell research in six main areas: Cornea, Conjunctiva, Orbit, Eyelid, Trabecular Meshwork and Retina.

\section{Cornea}

\subsection{Background}

The human cornea is highly specialized. The refractive index of a normal cornea is 1.376 and is essential to maintaining clarity of visual images on the retina. The cornea receives nutrition via glucose from the aqueous humour and oxygen through the tear film, although the peripheral cornea gets oxygen from the corneoscleral limbus. The cornea is composed of five layers: the epithelium, Bowman's layer, the stroma, Descemet's membrane and the endothelium (see Figure 2). The epithelium is composed of stratified squamous epithelial cells. These cells make up about $5 \%$ of corneal thickness. Perilimbal basal epithelial cells give

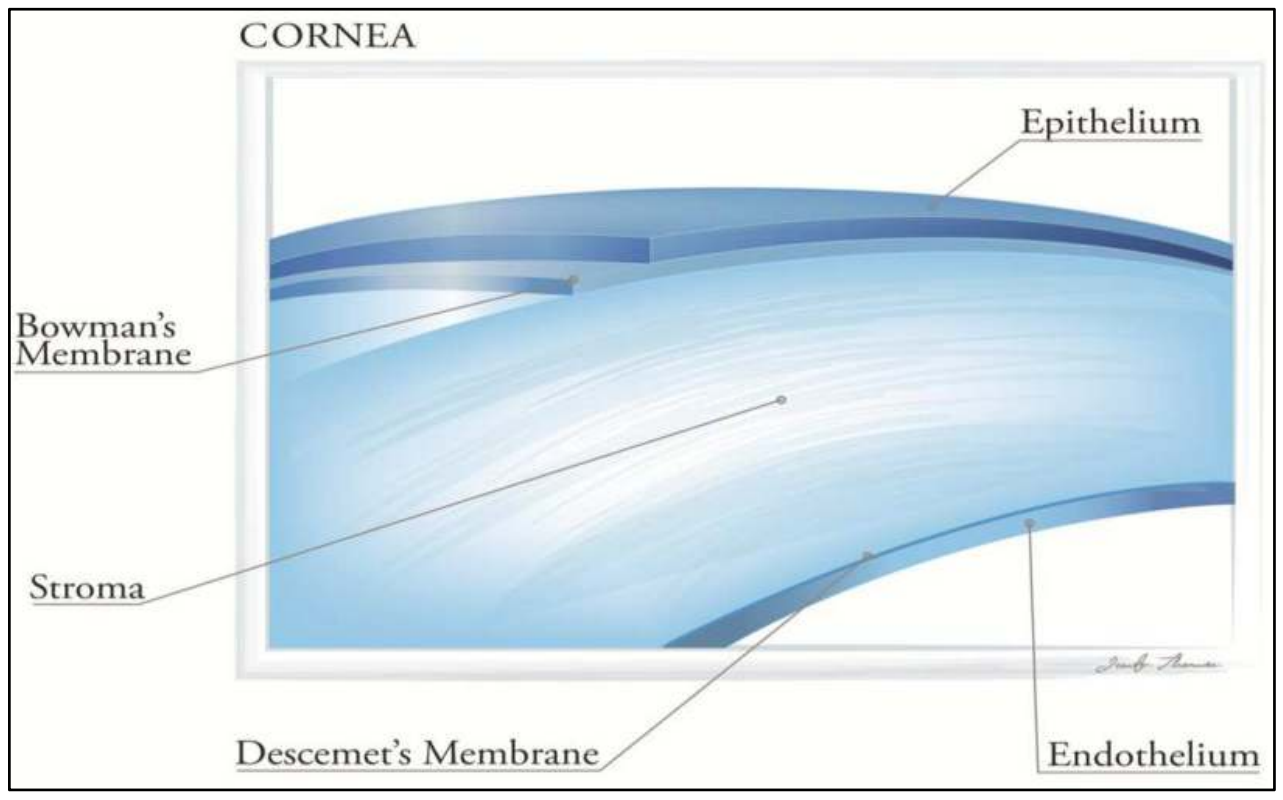

Fig. 2. Anatomy of the Cornea (Illustration by Jennifer Thomson Ph D., Bascom Palmer Eye Institute, University of Miami Miller School of Medicine) 
rise to superficial cells which then desquamate into the tear film over a period of one to two weeks. Constant renewal of the epithelial cells is essential to the cornea's visually essential role of light transmittance and refraction. With each blink, superficial epithelial cells may be shed into the tear pool, and these cells must be constantly repopulated from epithelial stem cells.

The stroma is also essential to the maintenance of clear vision. It is composed of keratocytes in a lattice arrangement, which reduces light scattering by destructive interference. The lattice is smaller than the wavelength of visible light, an essential characteristic to maintaining corneal clarity. Corneal transparency also depends on corneal hydration which depends on the endothelial pump. The endothelium is especially susceptible to damage as endothelial cells do not proliferate and cell loss leads to enlargement and spread of neighboring cells to cover the defect.

Thus, each layer of the cornea is essential to maintaining clarity of visual images. The discovery of the location of corneal epithelial stems cells at the limbus (the junctional zone between the cornea and conjunctiva) was one of the first major stem cell advances in the field of ophthalmology, and was proposed in the early 1970s (Davanger and Evenson, 1971).

\subsection{Stem cell localization}

An extensive review of corneal stem cells will be documented in the chapter Limbal Stem Cell Transplantation and Corneal Neovascularization by Katikireddy and Ula. The purpose of this section of the chapter is to provide a brief overview of corneal stem cells in the context of other stem cell research in ophthalmology, such as in extensive ocular surface disease.

The corneal limbus was first proposed in 1971 as the site of corneal stem cells based on the observation that pigment migrated from the limbus to the central cornea in healing corneal defects (Davanger \& Evenson, 1971). Subsequent studies demonstrated that slow-cycling limbal epithelial basal cells retained tritiated thymidine (Cotsarelis et al, 1989), supporting the notion that this was the location of stem cells. In addition, keratinocyte growth factor (KGF) is known to stimulate limbal epithelial precursor cells to grow (Wilson et al, 1994), and limbal epithelial cells exhibit higher levels of KGF compared to similar corneal epithelial cells (Li \& Tseng, 1997). Interestingly, corneal epithelial cells grown on limbal stroma also revert to a more proliferative cell type (Espana et al, 1987). In addition, stem cell markers such as p63 (Pelligrini et al, 2001) and transporter ABCG2 (Watanabe et al, 2004) have been identified in the limbal cell population. Even studies on the distribution of stem cells in the human corneal stroma and endothelium which found precursor cells distributed throughout the cornea show that the peripheral cornea has the large majority of the stem cell population (Yamagami et al, 2007).

How does this translate into the clinical setting? In culture, limbal basal cells have the highest proliferative capacity, diseases affecting the limbus result in delayed healing and conjunctival overgrowth, and limbal transplants can regenerate corneal-like epithelium. These findings all support the premise that the corneal surface is renewed by limbal stem cells in both normal physiological conditions and after injury.

What are the key characteristics of corneal stem cells? Corneal stem cells are characterized by small size, low rate of replication, and expression of a side population (SP) phenotype (Watanabe et al, 2004), a common feature of stem cells in other organ systems. These cells represent only a minor fraction of the cell population in the cornea. In the mouse model, these limbal stem cells only represent from $<1 \%$ (Budak et al, 2005) to 3.8\% (Krulova et al, 2008) of the limbal cell population. In rat and human cornea, flow cytometry and analysis of 
certain stem cell markers (such as ABCG2 expression) has shown that these cells range from $0.20 \%$ (Watanabe et al, 2004) to $10 \%$ (Umemoto et al, 2005) of the total limbal epithelial cell population. The small fraction they represent is important in understanding techniques for extraction and cultivation of stem cells.

What about the stem cell niche? Even in tissues with a high turnover rate, such as the cornea, there are a proportion of stem cells among this population that are quiescent and reactivate only in specific situations such as injury or trauma (Wang et al, 2010). This stem cell "niche" hypothesis maintains that upon stem cell division one cell remains a stem cell and returns to replenish the stem cell supply while the other becomes differentiated to repair and resupply lost cells (Schofield, 1983). In addition, the niche in which stem cells reside provides ongoing nutritional support and protection. For example, in the cornea the stem cells at the limbus are close to blood vessels which can provide essential nutrients and allow for ongoing proliferation. The properties and environment which lead to support and proliferation of stem cells as well as maintenance of supply are key factors to the successful treatment of diseases with limbal stem cell deficiency.

\subsection{Pathology}

The protective microenvironment which maintains the stem cell population and allows for self-renewal is extremely important. Any disruption in this environment can damage the stem cells and cause pathologic changes with significant consequences, such as occurs in limbal stem cell deficiency. There are congenital and acquired forms of limbal stem cell deficiency. For example, aniridia is a congenital ocular disease associated with limbal stem cell deficiency. More commonly, limbal stem cell deficiency develops due to local tissue injury. Stevens Johnson syndrome (see Figure 3), ocular cicatricial pemphigoid, chemical or thermal burns, severe contact lens keratopathy, surgical damage to the limbus and other cicatrizing disease can all lead to a deficiency in these important cells.

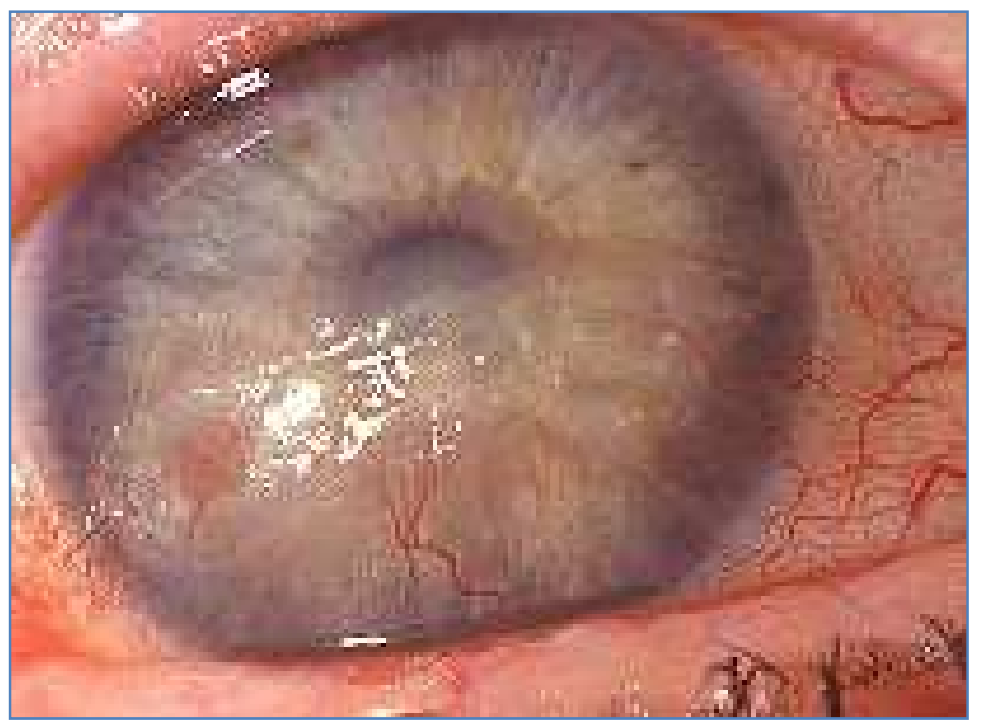

Fig. 3. Corneal scarring from Stevens Johnson Syndrome (Courtesy of Miami VA Hospital Photography Department) 
Typically, when limbal stem cell deficiency occurs, the neighboring conjunctival cells (normally hindered by limbal cells) migrate over the cornea and cause conjunctivalization (corneal neovascularization, appearance of goblet cells and an irregular epithelium) (Daniels et al, 2001). The result of this overgrowth is poor vision, corneal opacity, surface irregularity and patient discomfort. In the cornea, the identification of limbal stem cells has enabled advances in not only the diagnosis of corneal disease but also in treatment options for patients with severe limbal stem cell deficiency.

\subsection{Treatment}

In certain severe ocular diseases with corneal compromise, treatment of limbal stem cell deficiency was initially demonstrated to be effective via transplantation of limbal allografts, autografts or keratoepithelioplasty (Frucht-Pery et al, 1998) (Kenyon \& Tseng, 1989). Limbal allografts, however, carry a high risk of rejection because of the presence of specific antigens which are more likely to stimulate an immune response (Pels \& van der Gaag, 1984). As a result, they require long term immunosuppression. In addition, cadaver grafting, which in cases of severe bilateral disease is sometimes the only option, has a high failure rate compared to living related donor in the treatment of total limbal stem cell deficiency (Miri, Al-Deiri et al, 2010). This form of grafting has been associated with poor clinical outcomes. Prolonged inflammation due to the ongoing disease process can also destroy corneal stem cells and substantially increases the risk of any surgical intervention in these cases. As such, limbal transplantation is contraindicated in patients with severe dry eye given the low chance of survival of the graft (Dua et al, 2010). Given these factors, it is important that an extensive ocular evaluation is performed including eyelid position and function, ocular surface lubrication and presence or absence of dry eye syndrome, visual potential of the eye, condition of the fellow eye and systemic health of the patient (especially when allografts are planned and immunosuppression is required). Treatment of ocular or systemic comorbidities is essential to the long-term success of stem cell transplantation in the eye, just as in other organ systems.

The following general algorithm for surgical intervention in cases of stem cell deficiency was proposed (Dua et al, 2010):

1. Partial stem cell deficiency with no involvement of the visual axis, aggressive lubrication

2. Partial stem cell deficiency with visual involvement, sequential sector conjunctival epitheliectomy (SSCE)

3. Partial stem cell deficiency with pannus, SSCE with a sector limbal transplant

4. Total unilateral stem cell deficiency, autolimbal transplantation

5. Total bilateral stem cell deficiency use of allografts from a living related or cadaver donor

For partial stem cell deficiency, amniotic membrane transplantation with superficial keratectomy is also a viable treatment option (Anderson et al, 2001). The details of the surgical procedures are beyond the scope of this chapter, but the extensive algorithm summarizes the significant advances that have taken place in terms of our understanding of the anatomy, pathology and treatment options for stem cell deficiency in the cornea.

\subsection{Further stem cell applications and new advances}

Limitations of the aforementioned treatment modalities have led to treatment of unilateral or bilateral total stem cell deficiency with ex vivo expansion of limbal derived cells with or 
without a substrate (Dua et al, 2010). Ex vivo transplantation uses cells from a small biopsy sample which are cultured to generate cohesive sheets of corneal epithelium. This epithelium can then be transplanted (Pelligrini et al, 1997). Several techniques are used for producing ex vivo cultured limbal epithelial cells for transplantation. The explants culture system and the suspension culture system have been shown to have similar success rates (Shortt et al, 2007). Ex vivo cultured oral mucosal epithelium has also been used to treat limbal stem cell deficiency (Inatomi et al, 2006). While ex vivo expansion has the advantage of limited donor site morbidity because it only requires a small biopsy, it necessitates specialized techniques, takes time to generate the limbal stem cells and is very costly.

What about the niche environment? The success of limbal stem cell transplantation, whether ex-vivo or in-vivo, is also not surprisingly dependent on the limbal stem cell niche environment. Processing of cultured limbal stem cells may become more efficient and treatments more efficacious as these factors are elucidated. In fibroblast cultures from the cornea, limbus and sclera of donor ocular tissue, only corneal and limbal fibroblasts supported limbal epithelial precursor culture establishment; limbal fibroblasts also had significantly better growth (Ainscough et al, 2011). Scleral fibroblasts had increased myofibroblast formation, which inhibited limbal epithelial stem cell growth, possibly preventing proliferation of limbal epithelial stem cells towards the sclera (Ainscough et al, 2011). These surrounding fibroblasts thus regulate the stem cell enrivonment. In addition, in the rabbit model, corneal stromal inflammation was associated with poor graft outcome (Tsai, \& Tseng 1995). The environment in which the cultured epithelial graft cells are placed is therefore important for the long term therapeutic effect.

How does this translate into clinical applications? Improved success of cultured limbal epithelial grafts may be obtained by "debriding" the wound of myofibroblasts. Stromal tissue substitutes that provide a good scaffold and hinder growth of myofibroblasts may lead to improved clinical outcomes (Ainscough et al, 2011). Transplantation with surrounding conjunctival tissue may lead to improved clinical results even in cadaver grafts (Dua et al, 2010). It is possible this frill of conjunctiva possesses factors which enhance clinical outcomes of transplantation. Co-transfer of limbal stem cells with other stem cells, such as mesenchymal cells, may also lead to improved outcomes by inhibiting local inflammation and improving healing through immunosuppressive properties of these cells (Zajicova et al, 2010). Furthermore, human amniotic membrane may serve as a niche for limbal stem cells, possibly through the suppression of apoptosis and expression of certain growth factors (Tseng et al, 1998). As such, amniotic membrane may contribute to the long term survival of cultured limbal stem cell transplantation (Tsai RJ \& Tsai RY, 2010). Understanding the milieu into which stems cells are to be transplanted for maximal success is essential to the advancement of these treatment options.

Therapy focused on reconstruction of the ocular surface in disease such as severe ocular burns, ocular cicatricial pemphigoid, Stevens Johnson Syndrome and others has thus been dramatically improved with limbal stem cell and amniotic membrane transplantation, with improved corneal clarity and clinical outcomes. As new growth factors are elucidated and stem cell culture techniques are developed, the treatment of corneal disease with stem cells will continue to advance. Further analysis of the location and level of markers such as CK3, CK19, p63, ABCG2, and vimentin (Ghoubay-Benallaoua et al, 2011) will enhance understanding of stem cell deficiency as well as stem cell treatment in the cornea and other organ systems. In addition, emerging advances in nanotechnology for stem cell application 
in the eye have shown that electrospun nanofibers can serve as a scaffold to grow and transfer limbal stem cells in the treatment of limbal stem cell deficiency (Zajicova et al, 2010). As biological discoveries identify key factors to stem cell survival and technological advances provide new biomaterials, the potential for improved treatment is dramatic.

\section{Conjunctiva}

\subsection{Background}

The conjunctiva is essential to ocular health as it contains essential support cells, provides for passage of fluids and nutrients and is a barrier to pathogen entrance and fluid loss. It functions to provide mucin for the tear film, immune defense (via production of antimicrobial peptides such as defensins as well as the conjunctiva associated lymphoid tissue - CALT), and a mechanical barrier. It is a thin transparent mucous membrane that is made up of a non-keratinized epithelium and a vascularized stroma. The epithelium varies from stratified cuboidal cells over the tarsus to columnar in the fornices to squamous on the globe. The basal cell layer contains goblet cells, which secrete mucin. The membrane covers the posterior surface of the eyelids and the anterior surface of the globe and is made up of the tarsal conjunctiva, forniceal conjunctiva, bulbar conjunctiva and the semilunar fold. The tarsal conjunctiva adheres firmly to the underlying tarsus. In contrast, the bulbar conjunctiva is loosely adherent to Tenon's capsule and has multiple folds, allowing for unrestricted ocular movement.

Therefore, the conjunctiva is essential to ocular health, providing a mechanical and immunological barrier to injury and infection, as well as contributing to the production and stability of the tear film through goblet cell secretion of mucin (Qi et al, 2010). Diseases of the conjunctiva can therefore have significant ocular morbidity.

Interestingly, there has been considerable debate regarding the role of the conjunctiva in corneal regeneration, and some have proposed that corneal and conjunctival epithelia are equipotent (Majo et al, 2010). Despite these findings and its essential role in ocular health, conjunctival stem cell biology has not been as well investigated as that of corneal stem cells (Ang \& Tan, 2004).

\subsection{Stem cell localization}

The location of conjunctival stem cells has been proposed to include the fornix (Wei, 1995), palpebral and bulbar conjunctiva (Pelligrini et al, 1999), bulbar conjunctiva (Qi et al, 2010; Chen et al, 2003), and mucocutaneous junction (Wirstschafter et al, 1999). Human bulbar and forniceal conjunctival cells have been found to have equivalent proliferative capacity, suggesting that conjunctival epithelial stem cells may be evenly distributed between the bulbar and forniceal conjunctiva (Pelligrini et al, 1999). Various keratins and molecules associated with stem cells were found in undifferentiated basal cells in the human bulbar conjunctival epithelium, supporting the localization of progenitor cells in this region (Qi et al, 2010). Research has focused on not only the location of these progenitor cells but also their differentiation potential. Interestingly, both conjunctival non-goblet and goblet cells are thought to be derived from a common progenitor (Pelligrini et al, 1999). This suggests that differentiation into goblet cells may occur late and these cells may be generated from transient amplifying cells (Schrader et al, 2010).

In pathological processes, a decrease in the conjunctival stem cell population has been demonstrated through staining for stem cell markers such as p63 in humans, rats and mice, 
which had reduced expression in damaged conjunctiva and conjunctivalized cornea (Moore et al, 2002). These discoveries and others have enhanced our understanding of conjunctival epithelial stem cells, which enables more appropriate surgical and medical treatment of conjunctival disease through advances such as tissue engineering.

\subsection{Pathology}

Cicatrizing ocular processes that affect the cornea can also affect the conjunctiva, such as ocular cicatricial pemphigoid, Stevens Johnson syndrome, graft versus host disease, autoimmune disease, post surgical changes and myriad other causes. Conjunctival disease and inflammation can lead to conjunctival thickening, forniceal foreshortening, symblepharon, severe dry eye due to poor blink dynamic, and subsequent keratinization of the ocular surface epithelia. In addition, damage to the goblet cells, ineffective blink and keratinization of the ocular surface epithelium can lead to disruption of the tear film and dry eye syndrome. Forniceal cicatrization can lead to cicatricial entropion and secondary trichiasis which damages the already susceptible corneal surface epithelium and makes the eye more prone to recurrent erosions, with the risk of secondary bacterial infection.

\subsection{Treatment}

Prolonged conjunctival inflammation can also deplete the limbal epithelial stem cell population, causing decreased vision through the mechanisms highlighted above. Given the interposition of conjunctival disease on corneal dysfunction, treatment of severe scarring, or cicatrizing disease, is fraught with associated complications, as discussed previously. Traditional treatment regimens have been staged, multi-specialty approaches. Prior to any corneal reconstruction, the ocular surface must be optimized so as to reduce the risk of subsequent failure (Gomes et al, 2003). Surgical reconstruction of the fornix can improve conjunctival function and lead to better long term success, with improved vision and comfort for the patient. The frequent ongoing inflammatory disease, however, can hinder long-term benefits.

Treatment modalities are all aimed at excision of scar tissue with placement of a tissue substitute to recreate the fornices and ocular epithelial surface. This can be achieved through mucous membrane grafting, conjunctival autografts, and amniotic membrane. Amniotic membrane transplantation has been used for severe cicatrizing conjunctival diseases, such as ocular cicatricial pemphigoid (Barabino et al, 2003). Inflammation at the time of grafting can have deleterious effects on outcomes (Tsai \& Tseng, 1995). Thus, transplantation is often performed in a staged surgical process whereby amniotic membrane transplantation is performed first to be followed by limbal transplantation in order to achieve the optimal result (Barabino et al, 2003). In cases of chemical burns with partial and total limbal stem cell deficiency, amniotic membrane transplantation has been shown to be an effective component of ocular surface reconstruction (Gomes et al, 2003). As previously highlighted, amniotic membrane may hinder apoptosis of essential cells and promote growth of stem cells essential to graft success (Tseng et al, 1998). When performed in conjunction with limbal stem cell transplantation, it is effective at improving the ocular surface in cases of limbal stem cell deficiency (Barabino et al, 2003).

Other bioengineered synthetic material also has the potential to help in cases of severe ocular surface disease. Acellular polymer (such as porous collagen-glycosaminoglycan copolymer matrix) grafting can minimize fornix contracture after injury by inhibiting early scar formation (Schrader et al, 2009). Engineered tissue substitutes are limited, however, 
because they do not have a donor epithelium and are often not elastic enough for forniceal placement. As with any surgical intervention in these cases, outcomes may be dependent on the level of inflammation. Features of the ideal transplant material include: low immunogenicity, high tolerance, easy surgical manipulation and elasticity, with an associated layer of donor epithelium available in cases of conjunctival stem cell deficiency (Schrader, 2009).

\subsection{Further stem cell applications and new advances}

While current transplantation techniques such as conjunctival autografts, oral mucous membrane grafts, nasal turbinate mucosa grafts and amniotic membrane are often used with benefit in patients with conjunctival stem cell deficiency and scarring, they are limited by complications secondary to the underlying stem cell deficiency and ongoing inflammatory disease. Long term success in patients with diffuse loss of conjunctival epithelial stem cells may require that the transplanted tissue contains epithelial stem cells (Pelligrini et al, 1999).

How are conjunctival epithelial stem cells transplanted? Conjunctival epithelial cells have been cultured in serum-free media. These cells have been shown to have a similar in vivo proliferative capability as those cultured in serum with $3 \mathrm{~T} 3$ feeder cells, mitigating the need for use of animal serum (Ang, Tan, Beuerman et al, 2004). A conjunctival epithelial equivalent has been developed using this serum-free culture system (Ang, 2004). Subsequently, autologous cultivated conjunctival cells grown in this manner on amniotic membrane have been successfully transplanted in primary pterygium (Ang et al, 2005). As in the cornea, conjunctival epithelial cell differentiation and growth on amniotic membrane in vitro has been demonstrated (Meller et al, 1999). Other synthetic materials, such as ultrathin poly(epsilon-caprolactone) membrane substrate, have been studied for possible transplantation and found to be biocompatible and able to support conjunctival epithelial cell proliferation (Ang et al, 2006).

What about the surrounding environment? Understanding the matrix and appropriate substrates for growth of these cells is an integral component of tissue transplantation success. The goal of treatment should be not only tissue replacement but also stimulation of new growth and proliferation of healthy tissue. Both the extracellular matrix and the coculture environment are essential to the proliferation and differentiation of conjunctival epithelial cells (Tsai \& Tseng, 1988; Tsai et al, 1994). Certain growth factors can also modulate the outcomes of stem cells. For example, when placed in the appropriate environment and with associated factors such as nerve growth factor ( $\mathrm{Li} \mathrm{W}$ et al, 2010), progenitor cells can differentiate into goblet cells (Ang, Tan, Phan et al, 2004). This is not surprising given the previous suggestion of the common origin of these cells (Pelligrini et al, 1999). Due to the essential role of goblet cells in the stability of the tear film, this is an integral part of restoring the ocular surface. Similar to limbal stem cells, support is also required in the stroma for conjunctival cell growth. Serum free co-culture of conjunctival epithelial cells with mitotically active subconjunctival fibroblasts stimulates the maintenance of conjunctival cells with stem cell characteristics (Ainscough et al, 2011). Thus, the conjunctival stromal scaffold and surrounding growth factors may also need manipulation in order to best support epithelial grafts.

All of these advances will continue to be translated into clinical application, allowing for improved treatment of severe conjunctival disease and it's potentially blinding sequelae. Cultivated conjunctival cells on amniotic membrane or biocompatible membranes can help 
improve the long term outcomes of surgical interventions in these difficult cases by stimulating new growth and creation of a new niche environment for stem cell proliferation.

\section{Orbit}

\subsection{Background}

The orbit provides the support framework for the eye. Each orbit is a bony cavity that contains the eye, optic nerve, extraocular muscles, nerves, fat, lacrimal gland, and blood vessels. Orbital anatomy is intricate and any disruption to the orbital tissue via inflammation, infection, trauma, scarring or neoplasm can cause significant visual consequences. In addition, multiple apertures and fossa connect the orbit to the surrounding structures of the cranium and sinus cavities. The proximity of the orbit to the cranial vault and nasal cavity can lead to neurological or nasal sequelae from orbital disease. In cases of more aggressive malignant tumors, tumor spread into the brain can lead to devastating neurological consequences. In addition, infectious processes, such as sinusitis, can spread from the sinuses into the orbital cavity and cause blindness. These infections can also spread into the brain and become life threatening.

Processes within the orbit are further complicated by the confined bony walls of the orbital cavity. For example, in cases of benign orbital tumors in the intraconal space such as cavernous hemangiomas, as the tumors grow they can sometimes compress the optic nerve and cause visual loss. In addition, all of the rectus muscles in the orbit originate from the annulus of zinn, a fibrous ring formed by their origin which encircles the optic foramen and the central portion of the superior orbital fissure. Diseases such as thyroid eye disease (TED) can lead to blindness by enlargement of these extraocular muscles causing compression of the optic nerve. For purposes of brevity, this chapter will focus on orbital adipose tissue and fibroblasts and one of the most common diseases affecting the orbit, thyroid eye disease (TED).

\subsection{Stem cell localization}

As stem cell research elsewhere has discovered, the human adipose tissue is a source of multipotent stem cells. Processed lipoaspirate cells can differentiate into osteogenic, adipogenic, myogenic, neurogenic and chondrogenic lineages and have many similar features to mesenchymal stem cells (Zuk et al, 2002). While adipose stem cells have been studied extensively throughout the body, research on the orbital adipose stem cell population is limited.

Interestingly, orbital adipocytes (which are continuous with the nasal fat pad) are derived from neural crest cells, versus adipose tissue throughout the body which is generally mesodermal in origin (Johnston et al, 1979). The central preaponeurotic fat has been presumed to be more similar to systemic adipose tissue and derived from mesoderm. The eyelid, therefore, provides a unique place to compare orbital stem cells (nasal fat pad) with fat more similar to systemic adipose tissue (central fat pads) (Korn et al, 2009). Both nasal and central adipose depots have been found to have the potential to differentiate into adipocytes, smooth muscle and neuronal/glial lineages (Korn et al, 2009). Interestingly, the nasal adipose stem cells expressed a higher level of antigens such as CD34 correlated with neurogenic differentiation potential. Conversely, central cells expressed more neuronal/glial associated antigens under the neurogenic environment used, suggesting that the pathway for differentiation is modulated at several levels (Korn et al, 2009). 
Further study of orbital adipose tissue is needed to understand the factors which lead to differentiation of this tissue and the neurogenic potential. Orbital adipose stem cell ability to differentiate into smooth muscle, neuronal lineages and adipocytes may also provide novel therapeutic treatments in disease affecting nerves, soft tissue, and muscles in the orbit. In addition, understanding the factors necessary for adipogenesis and expansion of the orbital adipose compartment in diseases such as TED has significant clinical applications. The ease of access to orbital adipose tissue makes it an interesting new target for stem cell research.

\subsection{Pathology}

Thyroid eye disease is an autoimmune inflammatory disease that has significant orbital consequences. Clinical signs of thyroid eye disease can vary from mild to severe and include proptosis (bulging of the eye), strabismus (double vision), bulging eyelids, exposure keratopathy, eyelid retraction and optic neuropathy. Enlargement of the extraocular muscles and expansion of the orbital fat from stimulation of orbital fibroblasts and adipogenesis in the fixed volume of the bony orbit can lead to these symptoms. Increased volume of the retroocular tissue and fibrotic changes can compress the optic nerve, cause extraocular muscle or eyelid dysfunction, or push the eye forward leading to corneal compromise.

The pathology of thyroid eye disease involves an autoantibody cross-reaction from the thyroid-stimulating hormone (TSH) receptor with orbital fibroblasts. This leads to orbital fibroblast stimulation of lymphocytes, release of various cytokines and stimulation of orbital fibroblast production of glycosaminoglycans that increase volume by osmotic edema. In addition, preadipocyte fibroblasts in this environment can differentiate into adipocytes, leading to expansion of the orbital fat cavity. De novo adipogenesis within orbital tissues is an important factor in the pathology of TED (Kumar et al, 2003). Proliferation of fibroblasts and adipocytes and secondary hyaluronan accumulation (among other aminoglycosides) causes tissue volume expansion, orbital congestion, exophthalmos, and compressive optic neuropathy (Kahaly et al, 1998). Differentiation of fibroblasts to adipocytes and proliferation of orbital fibroblasts are thus critical steps in the development of TED.

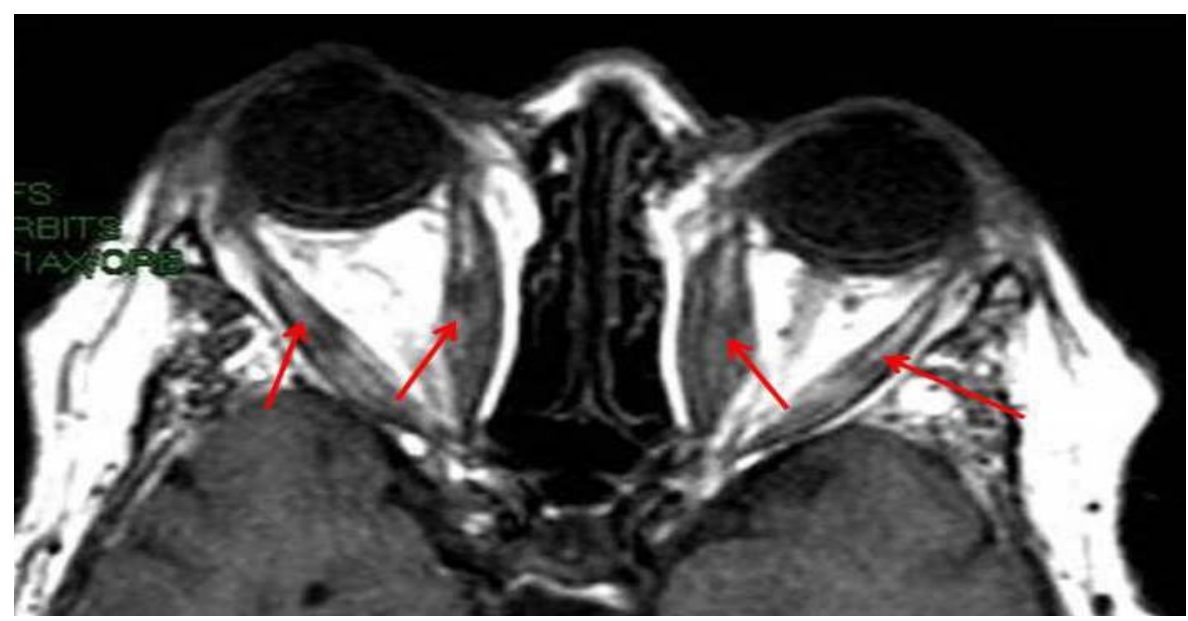

Fig. 4. Orbital Congestion from extraocular muscle enlargement in TED Note: arrows pointing to enlarged extraocular muscles 
Fibroblast proliferation and infiltration into muscle fibers leads to extraocular muscle fibrosis and disabling diplopia, which some classify as the first subtype of TRO, characterized by prominent extraocular muscle enlargement (see Figure 4) and diplopia (Hiromatsu et al, 2000). Fibroblast differentiation into adipocytes leads to accumulation of fatty tissue in the orbit, which has been classified by some as type two TED, associated with expansion of the orbital fat compartment and proptosis (Hiromatsu et al, 2000). Thus, a key aspect of the clinical progression of TED is the ability of these fibroblasts to differentiate into adipocytes and propagate at a pathological level.

\subsection{Treatment}

Traditional treatment of TED focuses on the ocular sequelae. Proptosis or eyelid retraction can lead to corneal exposure. Mild cases may be treated with medical management, such as aggressive lubrication, elevation of the head while sleeping, patching at night, and the use of eye shields. Patients with persistent symptoms despite these treatments may necessitate tarsorrhaphy (surgical closure of part of the eyelid) to help protect the cornea. In severe cases, orbital decompression (removing some of the bones of the orbit cavity to expand orbital volume) is sometimes indicated. Lid retraction and resultant exposure keratopathy are treated with aggressive lubrication, patching, botulinum toxin to the Müllers muscle, and sometimes a tarsorrhaphy in the near term; levator recession and lower lid retraction repair via a number of different techniques is used for permanent treatment of lid retraction. In cases of optic neuropathy from compression at the apex, steroids and surgical treatment with orbital decompression may be used. For disabling diplopia, radiation therapy and steroids may be of benefit. Surgical intervention is indicated once disease stability has been documented (with prisms and patching often recommended in the interim if the above treatment modalities are not sufficient). The order of any possible surgical intervention is important, with decompression prior to strabismus surgery followed by eyelid surgery, in order to achieve the best long-term outcome.

Despite various treatment options available, the ophthalmopathy may be progressive during times of thyroid dysfunction making surgical intervention more risky. In addition, some patients are not good candidates for surgery. Steroids are used as treatment in many cases, but the side effect profile of steroids is significant. As such, treatment advances have more recently been focused on alternative forms of immunomodulation (Salvi et al, 2006).

\subsection{Further stem cell applications and new advances}

Localization of orbital stem cells may help provide important therapeutic targets for TED. Preadipocyte fibroblasts in the adipose tissues are the precursor cells that differentiate into adipocytes in a process controlled by multiple regulatory genes and transcription factors (Sorisky, 1999). Preadipocyte fibroblast differentiation is associated with an increase in TSH receptor mRNA expression in patients with TED (Feliciello et al, 1993). Studies have also shown that cultured orbital preadipocytes can be induced in vitro to differentiate into adipocytes with functional TSH receptors (Valyasevi, 1992). Significant progress has been made into understanding the interactions between autologous T-lymphocytes and proliferation of fibroblasts (Feldon et al, 2005; Valyasevi et al, 1992). Understanding the factors that lead to differentiation of these fibroblasts into adipocytes as well as their proliferation in the orbit may help provide interventions to prevent this cell differentiation and stimulation. In addition, if orbital adipose stem cells are able to differentiate into 
neuronal, adipose and smooth muscle lineages, they may offer treatment options for myriad ocular conditions.

Orbital stem cells have been studied much less extensively than those in other areas of ophthalmology. The potential clinical applications for research in this area are broad. Orbital adipose tissue and the reservoirs of stem cells within are routinely excised during blepharoplasty surgery. As such, further research into these progenitor cells may provide insight on pathological processes affecting the orbit, such as TED. In addition, treatment modalities may be advanced through harvesting and differentiation of these stem cells.

\section{Eyelid}

\subsection{Background}

The eyelid is made up of an anterior and posterior lamella, both of which are essential to maintaining appropriate lid height, eyelid closure, blink dynamic, functioning of the nasolacrimal drainage system and protection of the globe. The skin of the eyelid is the thinnest in the body, with no underlying subcutaneous fat layer. Underlying the skin are the muscles of protraction, the orbicularis oculi, whose function can become altered by diseases such as seventh nerve palsies or benign essential blepharospasm. The orbital septum is the next layer which is a thin, multilayered sheet of fibrous tissue that separates preseptal from postseptal or orbital tissue planes. The fat lies posterior to the septum and anterior to the muscles of retraction, the levator palpebrae and the müllers muscle. Inferior to the müllers

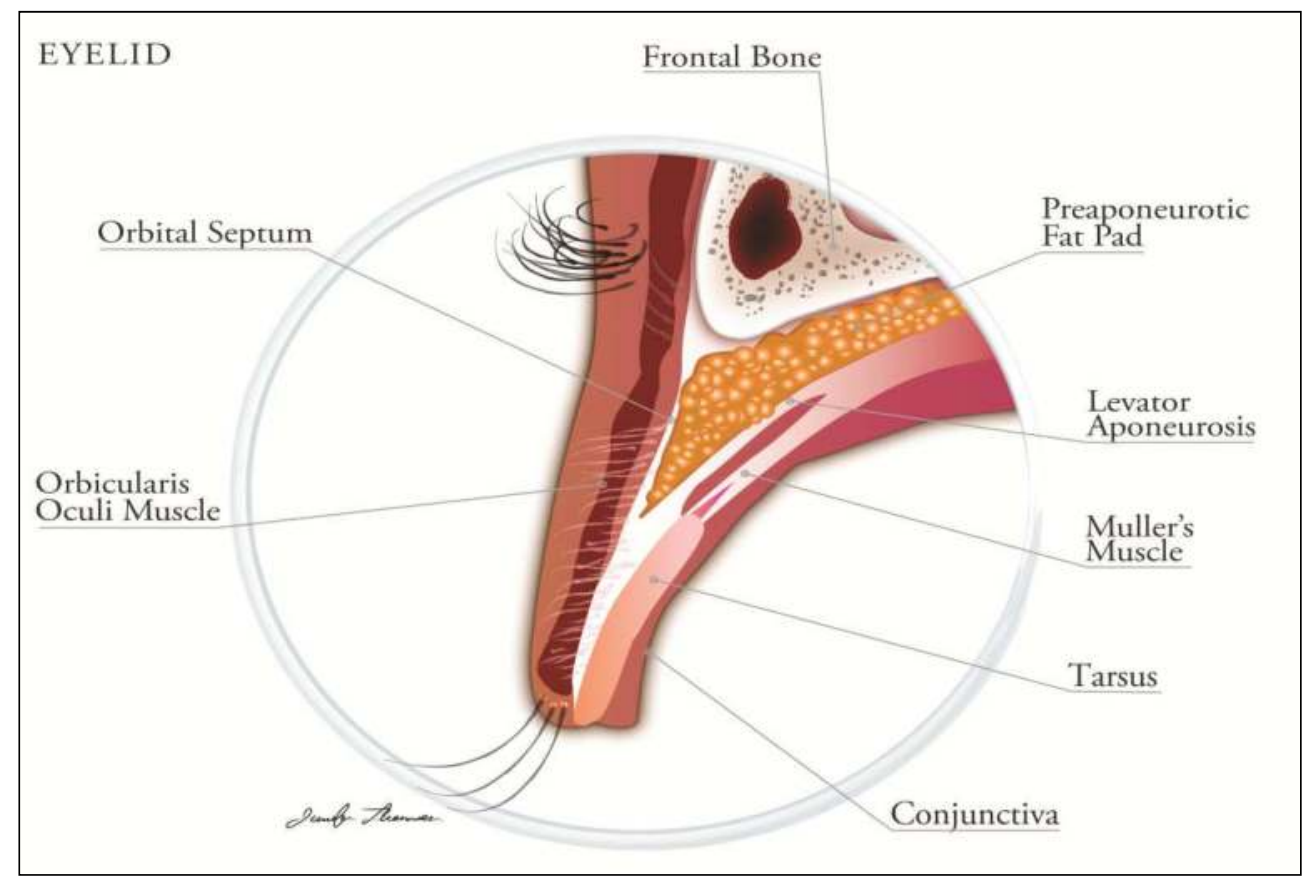

Fig. 5. Anatomy of the eyelid (Illustration by Jennifer Thomson Ph D., Bascom Palmer Eye Institute, University of Miami Miller School of Medicine) 
muscle is the tarsus, a firm, dense plate of connective tissue that serves as the "backbone" of the eyelid. The most posterior layer is the conjunctiva which extends from the mucocutaneous junction to the fornix (see Figure 5).

The purpose of this section is to discuss potential stem cell applications in cutaneous wound repair in the eyelid as well as neurogenic causes of poor orbicularis tone, namely facial nerve palsy. While stem cell applications may also extend to the muscles of retraction, the tarsus and posterior lamellar reconstruction, the chapter will focus on these two principal areas.

\subsection{Pathology}

Pathologic processes affecting the cutaneous layer of the eyelid are extensive. The primary relevance of stem cell research to the eyelid skin relate to tissue reengineering in the cases of loss of tissue that most often arise from cutaneous malignancy, orbital malignancy, or trauma. While only $15-20 \%$ of eyelid neoplasms are malignant, malignancy is becoming an increasingly common cause for severe loss of eyelid tissue. Basal cell carcinoma, squamous cell carcinoma, melanoma, sebaceous cell carcinoma as well as other much less frequent malignancies can invade locally, necessitating extensive resection. In cases of recurrent malignancies in patients who have undergone previous radiation, tissue shortage and poor vascular supply compound this issue.

In addition, traumatic and post-surgical cases of anterior lamellar deficiency can have significant potential ocular repercussions. Restoration of eyelid function is essential to the eye, as the eyelid functions to lubricate and protect the globe and eyelid opening is necessary for vision. Improper repair of eyelid defects or chronic wound healing problems can lead to loss of the vision and even loss of the eye.

\subsection{Stem cell localization}

Cutaneous wound repair in the eyelid, as in other places of the body, has been researched extensively. Wound healing and subsequent scar formation occurs through a cascade of events, including inflammatory, proliferative (granulation tissue deposition) and tissue remodeling phases. The details of these processes are beyond the scope of this chapter (see Lau et al, 2009 for a good review), but stem cells are integral to each of the phases. In the process of wound healing, several factors lead to a relatively hypoxic environment, in which bone marrow-derived mesenchymal stem cells thrive (Ren, 2006). Hypertrophic scars or keloids can develop from dysregulation of some of the processes involved in wound repair. Conversely, inadequate healing after radiation, infection, or in cases of poor vascular status often seen in diabetics or smokers can lead to insufficient wound repair.

Where are the stem cells? The major components of the epidermis with the potential for selfrenewal are the interfollicular epidermis, sebaceous gland and hair follicle. These are all repopulated by the differentiation of their own stem cells in physiologic conditions (Ko et al, 2011). In cases of skin injury, the stem cells become more pluripotent and are able to repopulate one another. For example, keratinocytes that reepithelialize a wound are derived from both the interfollicular epithelial stem cells and the hair follicle bulge stem cells (Lau et al, 2009). The interfollicular epithelial stem cells reside in the basal layer of the interfollicular epidermis. The hair follicle bulge epidermal stem cells are located in the outer root sheath of the hair follicle and play an essential role in epidermal healing in the early phases of wound repair (Nowak et al, 2008). In addition, the bulge epidermal stem cells retain a larger 
reservoir with age as opposed to the interfollicular stem cells which decline with age (Nowak et al, 2008). This tissue is easily isolated, allowing for easier procurement of these stem cells.

What about the surrounding environment? Angiogenesis plays a key role in wound healing, and is likewise dependent on surrounding stem cells. Precursor cells such as the "tissueresident endothelial precursors" and "pluripotent nestin expressing cells" (Lau et al, 2009) are important components to this process. In addition, as previously highlighted, adipose stem cells may also play a role in wound healing through promotion of angiogenesis. As with mesenchymal stem cells, adipose-derived stromal cells proliferate and support angiogenesis under the hypoxic conditions of wound healing (Lee et al, 2009). Chemokines also play an integral role as they induce wound repair via the accumulation of mesenchymal derived stem cells both in vitro and in vivo in the mouse model (Sasaki et al, 2008). It is thought that this process is modulated through paracrine signaling and the release of growth factors such as fibroblast growth factor and endothelial growth factors. Stem cells therefore contribute to wound healing both through repopulation of the cells that are essential for wound repair (i.e. keratinocytes) as well as modulating the wound repair process.

\subsection{Treatment}

Treatment of eyelid pathology is dependent on the underlying etiology and subsequent defect. Eyelid defects are repaired by sub-specialty trained Oculoplastic surgeons to reconstruct an anterior and posterior lamella best able to simulate normal anatomy. The myriad techniques for repair are beyond the scope of this chapter, but each is aimed at achieving the optimal functional and cosmetic result. In cases of severe trauma or tumor resection, the absence of an adequate amount of tissue for anterior lamellar reconstruction can be a complicating factor. Tissue expanders and other advances are helpful techniques in these types of patients, but tissue engineering with viable stem cell transplantation has potential significant applications.

\subsection{Further stem cell applications and new advances}

In patients with large eyelid defects from cutaneous malignancy requiring reconstruction, stem cells may help augment wound repair. In many patients with recurrent malignancy that have previously undergone radiation therapy, the risk of tissue necrosis is increased and stem cell promotion of angiogenesis may have an integral role. Patients with radiation damage may also have decreased functionality of their own stem cells. Certain factors integral to attracting stem cells to the wound, thus essential to the wound healing process, can also become deficient with age and diabetes (Ko et Al, 2010).

Because of the deficiency in stem cell functionality in cases of radiation, diabetes and age, stem cell application to these wounds may accelerate healing. Stem cell application to wounds using artificial dermis in patients with radiation injuries was shown to improve fat angiogenesis and dermal reconstitution, and minimize inflammatory epidermal damage (Akita et al, 2010). In addition, mesenchymal stem cells applied to wounds were found to accelerate wound closure and increase proangiogenic factors in both normal and diabetic mice (Wu et al, 2007). Translating these findings into clinical application, bone marrowderived stem cells were applied topically to non-healing wounds and led to clinical closure of the wound and histological evidence of reduced scarring (Badiavas \& Falanga, 2003). 
Accelerated closure of wounds was also demonstrated by topical application of autologous bone marrow-derived mesenchymal stem cells in culture via a fibrin spray system (Falanga et al, 2007). Biological skin substitutes with stem cells have also been found to be suitable for wound bed repair for future autografting in cases of full-thickness skin defects caused by burn or trauma in a Phase I/II study (Schurr et al, 2009). Such advances and the application of other technologies and biomaterials for the application of cells and growth factors to the wound all have potential clinical application in repairing severe eyelid defects.

In addition, as hair growth stimulation has been supported elsewhere by adipose stem cells, it is possible that these stem cells could also play a role in treatment of hypotrichosis and/or eyelash loss after eyelid reconstruction. Bimatoprost (Latisse ${ }^{\mathrm{TM}}$ ) has been shown to promote hair growth in several studies (Wester et al, 2010) and has been found to be beneficial in cases of hypotrichosis, but it requires ongoing application of the solution. In cases of severe hypotrichosis, it is possible that stem cells applied topically may have a benefit as well. Won et al studied hair growth from topical application and injection of adipose stem cells and suggest that these cells may promote hair growth by increasing the proliferation of dermal papilla cells through cell cycle modulation and activation of the anagen phase (Won, 2010). This may be important in hair loss surrounding surgical wounds and in treatment of hypotrichosis.

Stem cell research in the eyelid is in its nascency, but findings in other organ systems can be translated into wound repair. Future research may focus on application of cutaneous stem cell treatments to periocular regions. Research in this area may provide key therapeutic options for patients with significant soft tissue defects which can lead to inadequate ocular lubrication and blindness if not treated appropriately.

\section{Facial nerve}

\subsection{Background}

A number of peripheral nerves greatly impact ocular function. For example, the facial nerve, cranial nerve seven, arises in the pons and enters the petrous temporal bone into the internal auditory meatus (in close proximity to the inner ear), then runs a tortuous course through the facial canal. It travels the longest distance through a bony canal of any nerve in the body. After passing through the facial canal it emerges from the stylomastoid foramen and passes through the parotid gland, where it divides into five major branches (see Figure 6). The five major branches that exit the parotid gland include the temporal, zygomatic, buccal, marginal mandibular and cervical branch, all of which are essential to facial movement. The facial nerve also functions as the efferent limb of the corneal reflex and the blink reflex.

\subsection{Stem cell localization}

Stem cells in the area of denervated axons have been found to have an essential role in the attachment and growth of the regenerating axons. These cells contribute to the upregulation of multiple genes and downstream release of cytokines and growth factors which provides a stimulatory environment for nerve repair (Walsh 2009). Schwann cells also initially up-regulate multiple factors used for the attachment and growth of regenerating axons.

Over time, however, in the absence of axonal contact these cells slowly lose their capacity to proliferate and lose the ability to support axonal regeneration (Chen, 2010). Chronic denervation leads to a decrease in this capacity and a decline in the Schwann cell population, hindering further axonal regeneration (De Medinaceli \& Rawlings, 1987). The 
clinical implication is that axonal regeneration must occur during a "critical window" to maximize success of reinnervation.

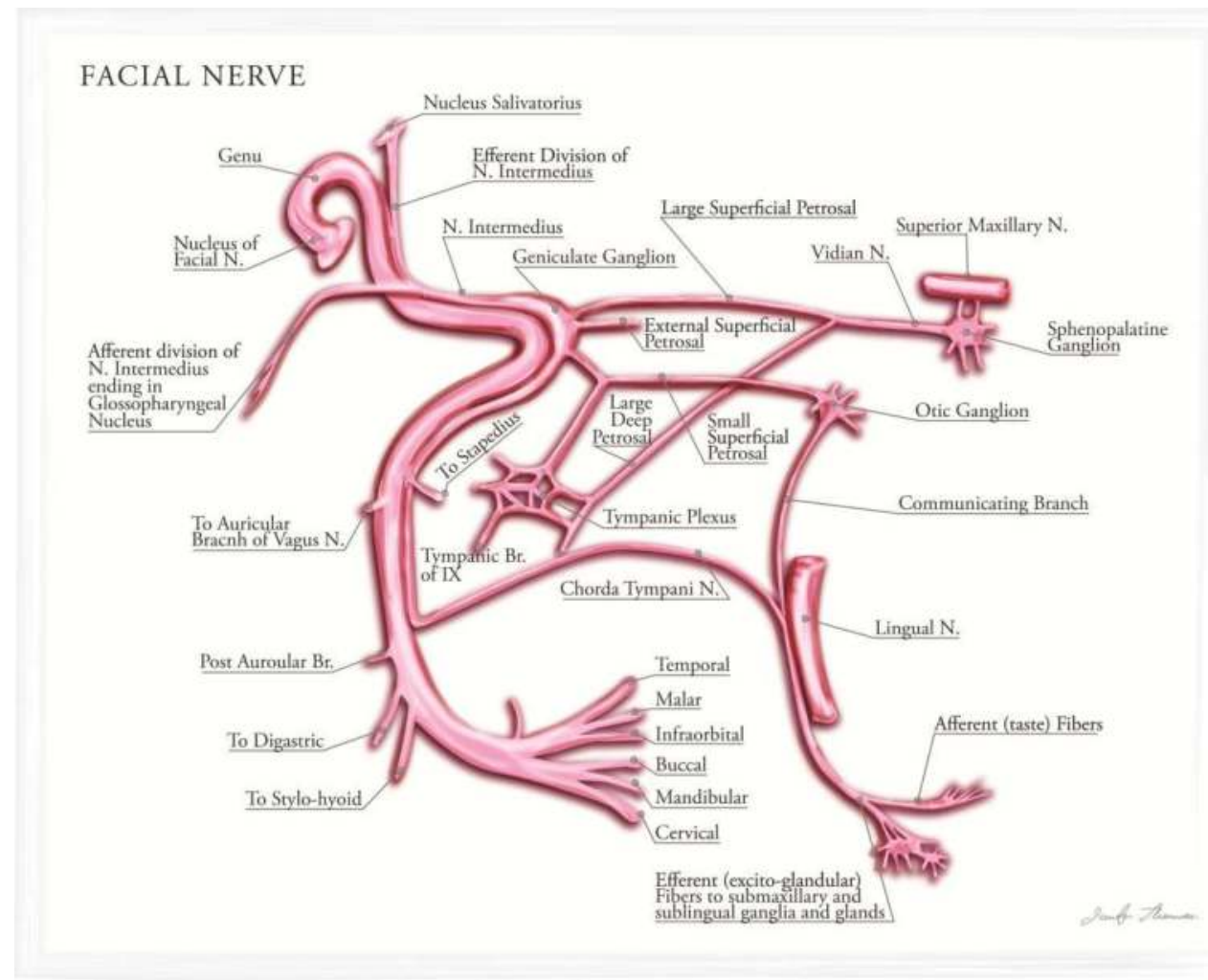

Fig. 6. Facial Nerve Anatomy (Illustration by Jennifer Thomson Ph D., Bascom Palmer Eye Institute, University of Miami Miller School of Medicine)

\subsection{Pathology}

Seventh nerve injury can affect the periocular tissue and eye and lead to chronic irritation, corneal infection, and even blindness. Seventh nerve palsy is a cause of paralytic ectropion that causes neurogenic orbicularis dysfunction and chronic ocular symptoms. Upper eyelid lagophthalmos from orbicularis dysfunction and poor blinking and eyelid closure causes chronic ocular irritation and potential infection. Chronic stimulation of reflex secretors causes secondary tearing, but poor blink dynamic and lid closure can lead to severe exposure keratopathy and infection. The etiology ranges from viral or other infectious causes to congenital or neoplastic causes, and trauma, toxic exposures, or iatrogenic causes. In addition, because of the long course and narrow caliber of the canal, inflammatory processes involving the central nervous system and facial nerve, and traumatic or other injuries to the temporal bone and surrounding structures can affect the function of the nerve.

The most common cause of unilateral facial paralysis is Bell's palsy, idiopathic facial paralysis, which accounts for the majority of cases of acute unilateral facial paralysis. The 
etiology has been attributed to several possible causes including viral (such as HSV), inflammatory, autoimmune, and ischemic etiologies. In the large majority of cases, Bell's palsy resolves spontaneously within the first few months (Ropper \& Samuels, 2009), but others may persist longer and have more significant consequences.

\subsection{Treatment}

Even the non-ophthalmic literature highlights that the most important primary consideration in the treatment of facial paralysis is protection of the eye and vision (Meltzer \& Alam, 2010). Temporary treatment includes artificial tears, ointment, eyelid taping, and moisture chambers. In cases without resolution, or other etiologies of seventh nerve dysfunction which are less likely to have spontaneous improvement, long-term treatment includes tarsorrhaphy, canthoplasty, gold weight placement, horizontal eyelid tightening, fascia lata or silicone suspension sling of the lower lid and full thickness hard palate mucosal grafting to the lower eyelid.

In cases of damage to a nerve via transection or other trauma, surgical repair is often indicated. Gaps or scars are particularly complicated to repair as the regenerating axons face a gap between the injury and the target (which becomes more difficult to overcome the longer the distance). Interpositional nerve grafts are often used as a treatment for longer gaps or scar segments to provide a pathway for regenerating axons, while direct repair can be used for shorter areas of denervation (Millesi et al, 1972). Current strategies use cable grafting in most cases of facial paralysis when primary repair is not possible, using greater auricular, sural or medial and lateral antebrachial cutaneous nerves (Humphrey \& Kreit, 2008). Importantly, these grafts are only recommended if they are performed within the time period during which reinnervation is possible.

Despite these treatments, however, recovery of nerve function is often suboptimal in cases of seventh nerve palsy. Prolonged degeneration in the distal denervated nerve leads to changes that render the Schwann cells less able to promote axon regeneration, thus limiting the success of these procedures over time (Meltzer et al, 2010). In addition, while peripheral nerves do regenerate better than the central nervous system, recovery can be incomplete or misdirected, even when surgical treatment is attempted. In the cases of facial nerve palsy, synkinesis (miswiring of nerves after injury) can lead to post paretic sequelae such as Marin Amat syndrome and crocodile tears. Chronic facial spasm can also develop after resolution of the facial nerve palsy. Surgical procedures in cases of chronic paralysis are often focused on static suspension procedures, regional myofascial procedures and free tissue transfer with the goal of achieving maximal symmetry. Ipsilateral and contralateral nerve transfers, static slings (such as used in the brow), dynamic muscle transfers, and gracilis microneurovascular free tissue transfer are all also used in the treatment of facial palsy, but have associated morbidities (Meltzer et al, 2010).

\subsection{Further stem cell applications and new advances}

Adipose and skin derived precursor cells have been shown to have the potential to differentiate and proliferate into Schwann and glial-like cells when treated with the appropriate medium (Zavan et al, 2010). While autologous nerve grafts remain the gold standard, harvesting of autologous stem cells and differentiation into neurogenic lineages has tremendous clinical potential in peripheral nerve injuries. The accessibility of skin and adipose derived stem cells may "bridge" the gap and allow translation of this into clinical 
applications in such areas as facial nerve palsies. Hair follicle bulge cells used to repair a peripheral nerve gap contributed to recovery of function by differentiating into glial cells (Amoh, 2005). Skin-derived stem cells injected into a nerve distal to a crush injury were found to associate with axons, express stem cell markers, and eventually express a myelinating phenotype (Walsh, 2009). Nerve repair in patients may be improved in the future by the use of autologous, cultured stem cells to help promote nerve regeneration. Skin and adipose derived stem cells have the added benefit that they can be easily harvested and have been shown to have neurogenic potential, as previously outlined.

\section{Retina}

The retina is developmentally an outgrowth from the forebrain, and like the rest of the central nervous system, exhibits neurodegenerative diseases that prove devastating to affected patients. Retinal degenerations often end with the death of retinal neurons, such as rod and cone photoreceptors in age-related macular degeneration and retinitis pigmentosa (discussed in section 7.1 below) and retinal ganglion cells in optic neuropathies such as glaucoma (discussed in section 7.2 below). Although it may be possible to salvage these cells before they die, for example, using neurotrophic factors or stem cells or gene therapy, for the many patients who have lost these cells, the challenge remains to figure out a way to replace them and thereby restore vision.

\subsection{Outer retina: Photoreceptors and retinal pigment epithelium \\ 7.1.1 Background}

Photoreceptors are the retinal cells that initiate vision by converting photons of light into chemical signals. In humans, photoreceptors are divided into rods and cones, which are responsible for dim, achromatic and brighter color vision, respectively. The center of the retina is more cone-dominant and the periphery more rod-dominant. Throughout the retina, photoreceptors are in close, critical contact with an adjacent layer of supportive cells, the retinal pigment epithelium (RPE). The RPE is responsible for phagocytosis of photoreceptor outer segments, critical to the constant replenishment of the membranous discs that house the photoreceptors' photon-conversion machinery. The RPE is also responsible for the replenishment of critical photopigments in the photoreceptor outer segments.

\subsubsection{Pathology}

Primary degeneration of either the photoreceptors or RPE leads to eventual degeneration of the other, and in either case degenerative loss of vision. Such pathologies are observed in a number of diseases, including common diseases like macular degeneration, and less common diseases such as retinitis pigmentosa.

Age-related macular degeneration (ARMD) is one of the most common causes of blindness worldwide (Klein et al., 2011). ARMD usually affects older adults and occurs in "dry" and "wet" forms. In dry ARMD, deposits called drusen accumulate between the retina and the choroid, and slow degeneration of RPE and later photoreceptors leads to localized "geographic" atrophy and central vision loss. In wet ARMD, new, leaky blood vessels grow up from the choroid behind the retina, leading to acute vision loss (Wong et al., 2008).

Retinitis pigmentosa is a collection of genetic diseases that generally start with night blindness and then continues on to tunnel vision, reflecting a pathology that affects rod photoreceptors in the peripheral retina earlier in the disease (Sahel et al.). Hundreds of 
different mutations in dozens of different primary genes lead to similar pathologies, including RPE hypertrophy, migration and proliferation and photoreceptor death (Daiger et al., 2007). Interestingly, these mutations may be found in either the photoreceptor or RPE cells, reinforcing the mutual interdependence of these two cell types.

\subsubsection{Current treatment}

Wet ARMD is currently treated with success using anti-VEGF antibodies (Mitchell, 2011); dry ARMD is slowed slightly by nutritional supplementation, at least in the later stages. Both of these sets of degenerative processes have in recent years become the target of a number of newer therapeutic approaches designed to slow, halt, or even reverse the disease process. Neurotrophic factors such as ciliary neurotrophic factor (CNTF) may provide neuroprotection (Sieving et al., 2006; Tao et al., 2002; Zhang et al., 2011). Gene therapy delivered with viral vectors may replace the defective gene (Ashtari et al., 2011; Cideciyan, 2010; Simonelli et al., 2009). However, both forms of the disease eventually lead to loss of photoreceptors and RPE cells, and these are not replaced through endogenous reparative mechanisms once lost. Thus there is considerable motivation to bring stem cell therapies to treat these diseases.

\subsubsection{Stem cell research and opportunities}

Significant steps forward have been made in using stem cells to replace photoreceptors and retinal pigment epithelium to address these diseases. Stem cells may prove therapeutic in two regards. As more commonly conceived, they may differentiate into the cell type lost in the disease, take up that cell's connections, and thereby replace that cell's function. However, it turns out stem cells also have remarkable properties of neuroprotection.

How do stem cells protect other cells from degenerating? One key way likely involves their expression and secretion of neurotrophic factors (Crigler et al., 2006) and immune system modulators that deter invading immune cells from creating neuronal death (Pluchino et al., 2005). Their neuroprotective activity can be further enhanced by transducing them with vectors that further increase their expression of specific neurotrophic survival factors (see section 7.2.4). An attraction to harnessing the neuroprotective effects of stem cell transplantation is that it does not require any specific differentiation and integration: the transplanted cells need only persist locally, for example in the vitreous or subretinal space. Success with such approaches has been demonstrated in rat and mouse models of retinitis pigmentosa (Arnhold et al., 2007; Inoue et al., 2007).

A major advantage in thinking about cell replacement therapy approaches for these diseases is that photoreceptors and RPE cells only have to interact with local, neighboring cells to carry out their full roles in retinal physiology (Lamba et al., 2009b). A number of stem cell therapies are approaching human clinical investigation now, including trials in the United Kingdom, Israel and the United States. All three of these are directed at the use of stem cellderived RPE cells implanted subretinally to resume the function of lost RPE and thereby protect photoreceptors from further degeneration (Lu et al., 2009; Lund et al., 2006). Similar approaches for photoreceptor replacement have demonstrated some success (Lamba et al., 2009a) and may be aided by treatments that manipulate the host retinal environment to encourage grafting and integration, for example through steroid treatment (Singhal et al.), matrix metalloproteinase manipulation (Zhang et al., 2007), or disruption of the outer limiting membrane of the retina (West et al., 2008). 
A number of cell sources may prove valuable for replacing photoreceptors, although direct comparison of different cell sources has not yet been performed. One study recently examined retinal progenitors isolated from different developmental stages, and found that donor cells from retinas at an age close to photoreceptors' peak birthdate in vivo demonstrated the greatest integration after transplantation (Hernit-Grant \& Macklis; MacLaren et al.). , and postmitotic rod precursors reintegrated synaptically in the photoreceptor layer better than multipotent progenitor cells. Transplantation of immature rods improved visually evoked potentials in mouse models of retinitis pigmentosa, either by direct synaptic input or by improving the function of the residual photoreceptors (MacLaren et al.).

Can we harvest retinal stem cells from patients? Recently, it was demonstrated that in adult humans, a small population of stem cells reside at the edge of the retina, called the ciliary marginal zone (Coles et al., 2004; Tropepe et al., 2000). It is unclear where these cells come from during development, or whether they have any normal role to play in the retina. Importantly, however, if you remove them from the eye into cell cultures, they can proliferate and be induced to differentiate into all the cell types in the retina, including rods and cones (Coles et al., 2004; Tropepe et al., 2000). Such a technique could benefit patients by offering a source of retinal progenitor cells that are autologous (from the patient themselves), or allogeneic (from a matched donor), for example. However, many questions remain, including how to optimally support these progenitor cells' proliferative capacity, and how to guide their differentiation into specific retinal neurons such as photoreceptors or retinal ganglion cells.

\subsection{Inner retina and optic nerve}

\subsubsection{Background}

Retinal ganglion cell axons originate at the retinal ganglion cell bodies in the inner layer of the retina. Retinal ganglion cells receive synaptic signals from inner retinal bipolar and amacrine cells, and project this visual information down their axon in the nerve fiber layer. The optic nerve begins at the optic nerve head or optic disk, and from there through the orbit (Wolff, 1948) and optic canal (Maniscalco \& Habal, 1978) to the chiasm, optic tract and into the brain.

\subsubsection{Pathology}

The inner retina and optic nerve are commonly involved in disease, resulting in retinopathy and optic neuropathy, and thus visual loss. Vein occlusions, in which the inner retinal circulation is compromised, are the most common cause of inner retinal injury, damaging retinal ganglion cells as well as amacrine cells but sparing the outer retina including photoreceptors (Laouri et al., 2011). Less common, retinal artery occlusions have the same effects (Mangat, 1995). More specific damage to retinal ganglion cells occurs when the ischemic insult is observed at the optic nerve in arteritic and non-arteritic anterior ischemic optic neuropathies. This is generally accompanied by a pale disk and loss of optic nerve axons. Ischemia in either location may result from hypotension or from occlusive or embolic disease (Connolly et al., 1994; Johnson et al., 1987).

Glaucoma is the most common optic neuropathy and the most common cause of irreversible blindness worldwide (Quigley \& Broman, 2006). Glaucomatous optic neuropathy is distinguished by a distinct morphology of progressive excavation of the nerve head without 
significant pallor of the remaining neuroretinal rim. Within the retina, there are decreased numbers of retinal ganglion cell bodies in glaucoma (Giles \& Soble, 1971; Minckler, 1989; Quigley, 1995), and this likely reflects death by apoptosis (Dkhissi et al., 1999; Kerrigan et al., 1997; Okisaka et al., 1997; Quigley et al., 1995). The number of retinal ganglion cells lost correlates with the visual field deficit (Quigley et al., 1989). In addition to the retinal ganglion cell body loss, there is loss of the ganglion cell axons, manifested by segmental loss of the nerve fiber layer (Airaksinen et al., 1984; Drance, 1985; Hoyt et al., 1973; Iwata et al., 1985; Quigley et al., 1980), increased cup-to-disk ratio, thinning of the optic nerve (Stroman et al., 1995) and chiasm (Iwata et al., 1997), changes in post-synaptic cell counts within the lateral geniculate nucleus (Chaturvedi et al., 1993; Vickers et al., 1997; Weber et al., 2000; Yücel et al., 2000) (the main target of retinal ganglion cell axons in higher animals), and even the cerebral cortex (Crawford et al., 2001; Crawford et al., 2000).

Other optic neuropathies include optic neuritis, ischemic optic neuropathy and compressive optic neuropathy, commonly associated with a tumor or aneurysm. Examples of these tumors include cavernous hemangioma, hemangiopericytoma, fibrous histiocytoma, lymphoma, and schwannoma. In addition, enlargement of the orbital extraocular muscles themselves, as in Grave's ophthalmopathy, may compress the optic nerve and lead to death of retinal ganglion cells (see Section 5). Traumatic optic neuropathy and optic nerve transection are less commonly observed in humans but have been the best studied causes of retinal ganglion cell death in animal models. In humans, direct transection or even concussive injury to the optic nerve injures axons and leads to retinal ganglion cell death back in the retina. Optic neuritis is the most common inflammatory optic neuropathy in young adults (1997; Rizzo \& Lessell, 1988). Demyelination itself does not immediately cause loss of retinal ganglion cells; many rounds of inflammation and demylination eventually lead to axon loss (Evangelou et al., 2000; Perry \& Anthony, 1999; Trapp et al., 1998), which again clinically appears as optic atrophy and loss of the nerve fiber layer (MacFadyen et al., 1988).

What mechanisms induce retinal ganglion cell death in glaucoma and other optic neuropathies? Glaucoma, for example, has been extensively modeled in animals (reviewed in (Morrison et al., 2005; Whitmore et al., 2005). Studies of tissue from human patients with glaucoma and non-human primates and other mammals with experimental glaucoma confirm changes at the optic nerve head, such as with respect to bowing out of the lamina cribrosa, intra-axonal accumulation of organelles (consistent with blocked axonal transport), and Wallerian degeneration distal to the lamina cribrosa (Fontana et al., 1998; Quigley \& Addicks, 1980; Quigley et al., 1981). Whether due to mechanical trauma of axons (Allcutt et al., 1984a; Allcutt et al., 1984b; Barron et al., 1986; Berkelaar et al., 1994), ischemia (Cioffi \& Sullivan, 1999), generation of nitric oxide (Neufeld, 1999; Neufeld et al., 1997), or other causes, axonal injury causes changes in retinal ganglion cells, eventually resulting in death. Increased intraocular pressure perturbs rapid anterograde and retrograde axonal transport at the lamina cribrosa (Anderson \& Hendrickson, 1974; Minckler et al., 1977; Quigley et al., 1979; Radius, 1983). This may cause retinal ganglion cells to be deprived of neurotrophic factors or other survival signals produced by brain targets. Studies in experimental animals have shown that injury to the optic nerve, for example from increased intraocular pressure in experimental glaucoma, blocks the retrograde transport of the neurotrophic factor brainderived neurotrophic factor (BDNF) along with its associated receptor, TrkB (Johnson et al., 2000; Pease et al., 2000; Quigley et al., 2000). Interestingly, one of the genes associated with a 
hereditary form of glaucoma, optineurin (Rezaie et al., 2002), may in its mutated form contribute to retinal ganglion cell sensitivity to optic nerve insults by failing to adequately participate in retrograde transport of neurotrophin signaling complexes, or by redox dysregulation (Anborgh et al., 2005; Chalasani et al., 2007; De Marco et al., 2006; Park et al., 2006).

\subsubsection{Current treatment}

Current treatment for optic neuropathies and optic nerve and retinal ischemias is directed almost exclusively at reducing risk factors for disease progression. For example, primary open-angle glaucoma therapy is focused on reducing the only known modifiable risk factor, intraocular pressure (discussed in section 8, below). Retinal and optic nerve ischemia treatment is directed at reducing identifiable risk factors such as uncontrolled diabetes or hypertension. All of these treatments, however, are directed at reducing disease progression or preventing recurrence. There are no current treatments able to restore function already lost once retinal ganglion cells die or their axons are severed in the optic nerve. Thus, there is considerable clinical need for novel therapeutics directed at enhancing function through restoration of lost cells and connectivity, as well as improved approaches to neuroprotection, similar to that discussed for the photoreceptor/RPE complex above.

\subsubsection{Stem cell research and opportunities}

There is considerable promise regarding the use of stem cells for glaucoma and other optic neuropathies, although most of this work has focused on the use of stem cells as neuroprotection delivery agents. Mesenchymal stem cells transplanted into the vitreous body in a rodent model of glaucoma showed considerable capacity to protect retinal ganglion cell degeneration (Johnson et al., 2010; Yu et al., 2006). This did not require any differentiation or integration of the transplanted stem cells. Similar results including RGC neuroprotection have been demonstrated in models of retinal ischemia ( $\mathrm{Li}$ et al., 2009).

As a cell replacement therapy for glaucoma, stem cells face a much tougher set of hurdles. Transplanted stem cells thus far have shown limited success at integrating into and restoring function elsewhere in the central nervous system in preclinical models (Calford et al., 2005; Sohur et al., 2006). Optimal cellular integration may be limited by immune reactivity, response to injury, or factors found in development but missing in the adult microenvironment. For replacing retinal ganglion cells, stem cells would have to properly differentiate into retinal ganglion cells, integrate with their presynaptic partners in the retina to receive visual information, and project their axons down the optic nerve and properly wire up with their targets in the lateral geniculate nucleus of the thalamus and other regions of the brain (Goldberg, 2003b).

Considerable progress on understanding how retinal ganglion cells differentiate from their precursors has been made. For example, two well-studied transcription factors, Math5 and Brn3, are required for initial and terminal differentiation, respectively. In the absence of Math5 expression, retinal ganglion cells fail to differentiate from retinal progenitors during development (Brown et al., 2001; Wang et al., 2001). Math5 normally activates the expression of Brn3 genes (Mu et al., 2005), but in the absence of Brn3 expression, retinal ganglion cells die shortly after their generation in the retina (Badea et al., 2009; Wang et al., 2002). Despite these and other steps forward in our understanding of retinal ganglion cell differentiation, we know little about how to force stem cells to differentiate into retinal ganglion cells with high efficiency. 
Considerable recent progress has been made in our understanding of how to encourage retinal ganglion cells to regenerate their axons through the optic nerve towards the brain (Moore \& Goldberg, 2011). A combination of inhibitory molecules in the optic nerve (Berry et al., 2008), insufficient neurotrophic factors available to promote axon growth (Aguayo et al., 1996), and a decreased intrinsic regenerative capacity of retinal ganglion cells after an early period of developmental growth (Liu et al., 2011) all contribute to regenerative failure, but overcoming these alone or in combination enhances regenerative ability (Benowitz \& Yin, 2007). A major question remains as to whether retinal ganglion cells derived from stem cells will also need to be treated to overcome these barriers to optic nerve axon growth and reconnection to the brain.

\section{Trabecular meshwork}

\subsection{Background}

The trabecular meshwork is a tissue in the angle between the cornea and iris in the anterior segment of the eye that is responsible for drainage of aqueous fluid. The ciliary body secretes aqueous fluid into the anterior chamber of the eye, which bathes and feeds the lens and cornea with critical nutrients (See Fig. 7). The balance between aqueous secretion and outflow is a major determinant of intraocular pressure (IOP), which is a major risk factor for the development of glaucoma (Goldberg, 2003a).

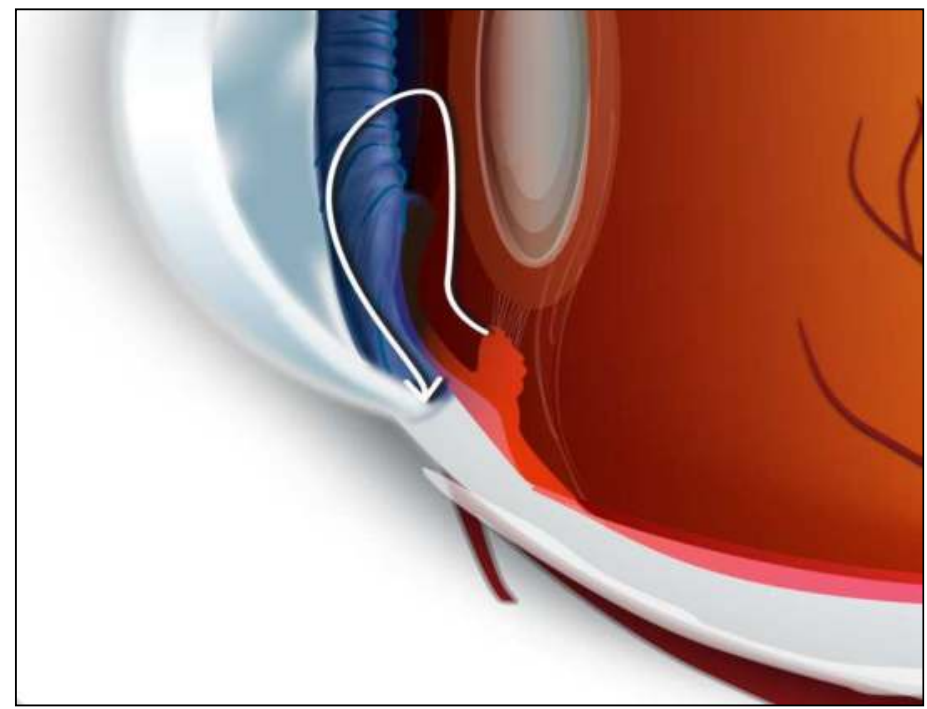

Fig. 7. Anterior chamber of the eye, with arrow demonstrating flow of aqueous humour (Illustration by Jennifer Thomson Ph D., Bascom Palmer Eye Institute, University of Miami Miller School of Medicine)

The trabecular meshwork is comprised of endothelial cells and extracellular matrix that separate the anterior chamber from an outflow track called Schlemm's canal. These trabecular meshwork cells may be divided into endothelial cells, juxtacanalicular cells, and Schlemm's canal cells, although the relationships between these anatomical distinctions is 
not well understood. The interaction between trabecular meshwork cells and the extracellular matrix, including the ability of the cells to phagocytose debris and thereby prevent clogging (Buller et al., 1990), is thought to create the mechanical relationships that determine outflow (WuDunn, 2009).

\subsection{Pathology}

In glaucoma, RGCs and their axons in the optic nerve demonstrate a typical pattern of damage and degeneration associated with permanent loss of vision, as discussed above. IOP is a major risk factor for glaucoma, although most people with IOP above population averages never develop glaucoma, and many people with "normal" IOP but particularly susceptible RGCs develop glaucoma. Randomized clinical trials have demonstrated that glaucoma patients with either "high" or "normal" starting IOPs can slow the progression of their disease by lowering IOP (reviewed elsewhere). Thus there is strong motivation to understand the dynamics of aqueous fluid production and outflow in the determining IOP and devising treatment strategies to lower IOP.

In glaucoma, changes in the cellular and molecular milieu of the trabecular meshwork have been observed. There is an age-dependent (Grierson \& Howes, 1987) and glaucomadependent (Alvarado et al., 1984; Alvarado et al., 1981) loss of trabecular meshwork cells. Cultured trabecular meshwork cells (Gasiorowski \& Russell, 2009) have provided a rich source of experimental evidence that their biology likely plays a role in determining outflow and thus IOP-associated glaucoma risk .

\subsection{Current treatment}

Current treatment for glaucoma is focused on lowering IOP, the only modifiable risk factor for primary open-angle glaucoma. Topical and oral medications designed to decrease aqueous production or increase outflow are typically first-line treatments, followed by laser trabeculoplasty and a number of incisional surgical approaches . Interestingly, laser trabeculoplasty may work by stimulating local cell replacement in the trabecular meshwork. Explanted human donor eyes treated with laser trabeculoplasty demonstrated increased cell division in the trabecular meshwork and in a line of cells located just anterior to the trabecular meshwork called insert cells (Acott et al., 1989; Alexander \& Grierson, 1989; Alexander et al., 1989; Dueker et al., 1990). Cells from this anterior zone were observed to migrate into the trabecular meshwork, raising the hypothesis that these were stem cells or progenitor cells for this tissue.

\subsection{Stem cell research and opportunities}

Human trabecular meshwork cells can now be isolated and cultured, and a subset of these cells in culture appear to behave like stem cells (or, trabecular meshwork progenitor cells) . Whether this proliferative population is derived from insert cells or a subpopulation of trabecular meshwork cells remains to be determined. trabecular meshwork progenitor cells can be expanded in three-dimensional sphere-like cultures (Gonzalez et al., 2006). Cells from these cultures express markers and gene expression profiles associated with monolayer cultures of TM stem cells (Gonzalez et al., 2006).

This raises the question, would transplanting trabecular meshwork cells or trabecular meshwork progenitor cells back to the trabecular meshwork enhance outflow, thereby lowering IOP and protecting RGCs from damage in glaucoma? There is little data yet 
exploring this question, but the observation that laser trabeculoplasty enhances both cellularity and trabecular meshwork outflow suggests that additional cells, if added in the right fashion, may remodel the trabecular meshwork to similarly reduce IOP. A number of groups are working on this hypothesis, and the relatively easy accessibility of the anterior segment makes this an attractive approach to consider cell therapies in the eye (Kelley et al., 2009).

\section{Conclusion}

In summary, there is considerable interest in and scientific basis for pursuing stem cell therapies in ophthalmology. From epithelial to mesenchymal and even endothelial cellbased approaches, the eye and periocular tissues present a range of diseases with immense clinical need for novel therapeutics. We look forward to the advances in both pre-clinical and translational research into cell therapies for ophthalmology, and predict a rapid and encouraging step into a new generation of stem cell-based therapeutics throughout the field.

\section{Acknowledgements}

The authors gratefully acknowledge support from the Department of Defense, the Hope for Vision foundation, the National Eye Institute (P30 EY014081, Miami), and an unrestricted grant from Research to Prevent Blindness. Illustration by Jennifer Thomson Ph D., Bascom Palmer Eye Institute, University of Miami Miller School of Medicine.

\section{References}

Acott TS, Samples JR, Bradley JM, et al. Trabecular repopulation by anterior trabecular meshwork cells after laser trabeculoplasty. Am J Ophthalmol. 107, (1989), 1-6.

Aguayo AJ, Clarke DB, Jelsma TN, et al. Effects of neurotrophins on the survival and regrowth of injured retinal neurons. Ciba Foundation Symp. 196, (1996), 135-44.

Ainscough S, Linn M, Barnard Z et al. Effects of fibroblast origin and phenotype on the proliferative potential of limbal epithelial progenitor cells. Experimental Eye Research, Vol. 92 (2011), pp. 10-19.

Airaksinen PJ, Drance SM, Douglas GR, et al. Diffuse and localized nerve fiber loss in glaucoma. Am J Ophthalmol. 98, (1984), 566-71.

Akhtiari P, Djalilian A. Update on Limbal Stem Cell Transplantation. Middle East Afr J Ophthalmol. Vol.17, No.1, (2010 Jan), pp. 9-14.

Akita S, Akino K, Hirano A et al. Mesenchymal Stem Cell Therapy for Cutaneous Radiation Syndrome. Health Phys, Vol.98, No. 6, (2010), pp.858-862.

Akpek EK, Foster SC. Limbal stem-cell transplantation. Int Ophthalmol Clin, Vol.39, (1999), pp.79-82.

Alexander RA, Grierson I. Morphological effects of argon laser trabeculoplasty upon the glaucomatous human meshwork. Eye (Lond). 3 ( Pt 6), (1989), 719-26.

Alexander RA, Grierson I, Church WH. The effect of argon laser trabeculoplasty upon the normal human trabecular meshwork. Graefes Arch Clin Exp Ophthalmol. 227, (1989), 72-7. 
Allcutt D, Berry M, Sievers J. A qualitative comparison of the reactions of retinal ganglion cell axons to optic nerve crush in neonatal and adult mice. Brain Res. 318, (1984a), 231-40.

Allcutt D, Berry M, Sievers J. A quantitative comparison of the reactions of retinal ganglion cells to optic nerve crush in neonatal and adult mice. Brain Res. 318, (1984b), 219-30.

Alvarado J, Murphy C, Juster R. Trabecular meshwork cellularity in primary open-angle glaucoma and nonglaucomatous normals. Ophthalmology. 91, (1984), 564-79.

Alvarado J, Murphy C, Polansky J, Juster R. Age-related changes in trabecular meshwork cellularity. Invest Ophthalmol Vis Sci. 21, (1981), 714-27.

Amoh Y, Li L, Campillo R, Kawahara K, et al. Implanted hair follicle stem cells form Schwann cells that support repair of severed peripheral nerves. Proc Natl Acad Sci USA, Vol. 102, (2005), pp.17734-17738.

Anborgh PH, Godin C, Pampillo M, et al. Inhibition of metabotropic glutamate receptor signaling by the huntingtin-binding protein optineurin. J Biol Chem. 280, (2005), 34840-8.

Anderson D, Ellies P, Pires R. Amniotic membrane transplantation for partial limbal stem cell deficiency. Br J Ophthalmol, Vol 85, (2001), pp.567-575.

Anderson DR, Hendrickson A. Effect of intraocular pressure on rapid axoplasmic transport in monkey optic nerve. Invest Ophthalmol. 13, (1974), 771.

Ang L, Cheng Z, Beuerman R et al. The development of a serum-free derived bioengineered conjunctival epithelial equivalent using an ultrathin poly(epsilon-caprolactone) membrane substrate. Invest Ophthalmol Vis Sci. Vol 47, No.1 (2006 Jan), pp.105-112.

Ang LP, Tan DT. Ocular surface stem cells and disease: current concepts and clinical applications. Ann Acad Med Singapore. Vol 33, No. 5, (2004 Sep), pp.576-580.

Ang LP, Tan DT, Beuerman RW, Lavker RM. Development of a conjunctival epithelial equivalent with improved proliferative properties using a multistep serum-free culture system. Invest Ophthalmol Vis Sci. Vol. 45, No.6, (2004), pp. 1789-1795.

Ang L, Tan D, Cajucom-Uy H et al. Autologous cultivated conjunctival transplantation for pterygium surgery. Am J Ophthalmol. Vol. 139, (2005), pp.611-619.

Ang L, Tan D, Phan T et al. The in vitro and in vivo proliferative capacity of serum-free cultivated human conjunctival epithelial cells. Curr Eye Res. Vol. 28, (2004), pp.307317.

Arnhold S, Absenger $\mathrm{Y}$, Klein $\mathrm{H}$, et al. Transplantation of bone marrow-derived mesenchymal stem cells rescue photoreceptor cells in the dystrophic retina of the rhodopsin knockout mouse. Graefes Arch Clin Exp Ophthalmol. 245, (2007), 414-22.

Ashtari M, Cyckowski LL, Monroe JF, et al. The human visual cortex responds to gene therapy-mediated recovery of retinal function. J Clin Invest. 121, (2011), 2160-8.

Badea TC, Cahill H, Ecker J, et al. Distinct roles of transcription factors brn3a and brn $3 \mathrm{~b}$ in controlling the development, morphology, and function of retinal ganglion cells. Neuron. 61, (2009), 852-64.

Badiavas EV, Falanga V. Treatment of chronic wounds with bone marrow-derived cells. Arch Dermatol. Vol. 139, No. 4, (2003), pp. 510-516. 
Barabino S, Rolando M, Bentivoglio G. Role of amniotic membrane transplantation for conjunctival reconstruction in ocular-cicatricial pemphigoid. Ophthalmology Vol.110, No. 3, (2003 Mar), pp.474-480.

Barron KD, Dentinger MP, Krohel G, et al. Qualitative and quantitative ultrastructural observations on retinal ganglion cell layer of rat after intraorbital optic nerve crush. J Neurocytol. 15, (1986), 345-62.

Benowitz LI, Yin Y. Combinatorial treatments for promoting axon regeneration in the cns: Strategies for overcoming inhibitory signals and activating neurons' intrinsic growth state. Dev Neurobiol. 67, (2007), 1148-65.

Berkelaar M, Clarke DB, Wang YC, et al. Axotomy results in delayed death and apoptosis of retinal ganglion cells in adult rats. J Neurosci. 14, (1994), 4368-74.

Berry M, Ahmed Z, Lorber B, et al. Regeneration of axons in the visual system. Restor Neurol Neurosci. 26, (2008), 147-74.

Brown NL, Patel S, Brzezinski J, Glaser T. Math5 is required for retinal ganglion cell and optic nerve formation. Development. 128, (2001), 2497-508.

Budak MT, Alpdogan OS, Zhou M et al. Ocular surface epithelia contain ABCG2-depending side population cells exhibiting features associated with stem cells. J Cell Sci. Vol. 118, (2005), pp.1715-1724.

Buller C, Johnson DH, Tschumper RC. Human trabecular meshwork phagocytosis. Observations in an organ culture system. Invest Ophthalmol Vis Sci. 31, (1990), 215663.

Calford MB, Chino YM, Das A, et al. Neuroscience: Rewiring the adult brain. Nature. 438, (2005), E3; discussion E3-4.

Chalasani ML, Radha V, Gupta V, et al. A glaucoma-associated mutant of optineurin selectively induces death of retinal ganglion cells which is inhibited by antioxidants. Invest Ophthalmol Vis Sci. 48, (2007), 1607-14.

Chaturvedi N, Hedley-Whyte ET, Dreyer EB. Lateral geniculate nucleus in glaucoma. Am J Ophthalmol. 116, (1993), 182-8.

Cideciyan AV. Leber congenital amaurosis due to rpe65 mutations and its treatment with gene therapy. Prog Retin Eye Res. 29, (2010), 398-427.

Cioffi GA, Sullivan P. The effect of chronic ischemia on the primate optic nerve. Eur J Ophthalmol. 9 Suppl 1, (1999), S34-6.

Coles BL, Angenieux B, Inoue T, et al. Facile isolation and the characterization of human retinal stem cells. Proc Natl Acad Sci U S A. 101, (2004), 15772-7.

Cotsarelis SZ, Cheng G, Dong G, et al. Existence of slow-cycling limbal epithelial basal cells that can be preferentially stimulated to proliferate: implications on epithelial stem cells. Cell. Vol 57, (1989), pp.201-209.

Connolly SE, Gordon KB, Horton JC. Salvage of vision after hypotension-induced ischemic optic neuropathy. Am J Ophthalmol. 117, (1994), 235-42.

Crawford ML, Harwerth RS, Smith EL, 3rd, et al. Experimental glaucoma in primates: Changes in cytochrome oxidase blobs in v1 cortex. Invest Ophthalmol Vis Sci. 42, (2001), 358-64. 
Crawford ML, Harwerth RS, Smith EL, 3rd, et al. Glaucoma in primates: Cytochrome oxidase reactivity in parvo- and magnocellular pathways. Invest Ophthalmol Vis Sci. 41, (2000), 1791-802.

Crigler L, Robey RC, Asawachaicharn A, et al. Human mesenchymal stem cell subpopulations express a variety of neuro-regulatory molecules and promote neuronal cell survival and neuritogenesis. Exp Neurol. 198, (2006), 54-64.

Daiger SP, Bowne SJ, Sullivan LS. Perspective on genes and mutations causing retinitis pigmentosa. Arch Ophthalmol. 125, (2007), 151-8.

Daniels J, Dart J, Tuft S et al. Corneal stem cells in review. Wound Rep Reg, Vol. 9, (2001), pp.483-494.

Davanger M, Evensen A. Role of the pericorneal papillary structure in renewal of corneal epithelium. Nature, 1971; 229: 560-1.

Daya SM, Watson A, Sharpe JR et al. Outcomes and DNA analysis of ex vivo expanded stem cell allograft for ocular surface reconstruction. Ophthalmology, Vol. 112, (2005), 470477.

De Marco N, Buono M, Troise F, Diez-Roux G. Optineurin increases cell survival and translocates to the nucleus in a rab8-dependent manner upon an apoptotic stimulus. J Biol Chem. 281, (2006), 16147-56.

De Medinaceli L, Rawlings RR: Is it possible to predict the outcome of peripheral nerve injuries? A probability model based on prospects for regenerating neurites. Biosystems, Vol.20, (1987), pp.243-258.

Dkhissi O, Chanut E, Wasowicz M, et al. Retinal tunel-positive cells and high glutamate levels in vitreous humor of mutant quail with a glaucoma-like disorder. Invest Ophthalmol Vis Sci. 40, (1999), 990-5.

Drance SM. The early structural and functional disturbances of chronic open-angle glaucoma. Robert n. Shaffer lecture. Ophthalmology. 92, (1985), 853-7.

Dua H, Miri A, Said D. Contemporary limbal stem cell transplantation - a review. Clinical and Experimental Ophthalmology, Vol. 38, (2010), pp. 104-117.

Dueker DK, Norberg M, Johnson DH, et al. Stimulation of cell division by argon and nd:Yag laser trabeculoplasty in cynomolgus monkeys. Invest Ophthalmol Vis Sci. 31, (1990), 115-24.

Espana E, Ti S, Grueterich M, et al. Corneal stromal changes following reconstruction by ex vivo expanded limbal epithelial cells in rabbits with total limbal stem cell deficiency. Br. J. Ophthalmol, Vol. 87, (2003), pp.1509-14.

Evangelou N, Esiri MM, Smith S, et al. Quantitative pathological evidence for axonal loss in normal appearing white matter in multiple sclerosis. Ann Neurol. 47, (2000), 391-5.

Falanga V, Iwamoto S, Chartier M, et al. Autologous bone marrow-derived cultured mesenchymal stem cells delivered in a fibrin spray accelerate healing in murine and human cutaneous wounds. Tissue Eng, Vol.13, (2007), pp.1299-1312.

Feldon S, Park DJ, O'Loughlin C, et al. Autologous T-Lymphocytes stimulate proliferation of orbital fibroblasts derived from patients with graves ophthalmopathy. Invest Ophthal and Vis Sci, Vol. 46, No. 11, (2005), pp. 3913-3921.

Feliciello A, Porcellini A, Ciullo L et al. Expression of thyrotropin receptor mRNA in healthy and Graves disease retro-orbital tissue. Lancet, Vol. 342, (1993), pp.337-338. 
Fontana L, Bhandari A, Fitzke FW, Hitchings RA. In vivo morphometry of the lamina cribrosa and its relation to visual field loss in glaucoma. Curr Eye Res. 17, (1998), 363-9.

Frucht-Pery J, Siganos CS, Solomon A. Limbal cell autograft transplantation for severe ocular surface disorders. Graefes Arch Clin. Exp Ophthalmol, Vol. 236, (1998), 582587.

Gasiorowski JZ, Russell P. Biological properties of trabecular meshwork cells. Exp Eye Res. $88,(2009), 671-5$.

Ghoubay-Benallaoua D, Basli E, Goldschmidt P et al. Human epithelial cell cultures from superficial limbal explants. Mol Vis, Vol. 17, (2011), pp. 341-354.

Giles CL, Soble AR. Intracranial hypertension and tetracycline therapy. Am J Ophthalmol. 72, (1971), 981-2.

Goldberg I. Relationship between intraocular pressure and preservation of visual field in glaucoma. Surv Ophthalmol. 48 Suppl 1, (2003a), S3-7.

Goldberg JL. How does an axon grow? Genes Dev. 17, (2003b), 941-58.

Gomes J, Serapião dos Santos M, Cunha M et al. Amniotic membrane transplantation for partial and total limbal stem cell deficiency secondary to chemical burn. Ophthalmology, Vol. 110, No. 3, (2003), pp.466-73.

Gonzalez P, Epstein DL, Luna C, Liton PB. Characterization of free-floating spheres from human trabecular meshwork (htm) cell culture in vitro. Exp Eye Res. 82, (2006), 95967.

Grierson I, Howes RC. Age-related depletion of the cell population in the human trabecular meshwork. Eye (Lond). 1 ( Pt 2), (1987), 204-10.

Hernit-Grant CS, Macklis JD. Embryonic neurons transplanted to regions of targeted photolytic cell death in adult mouse somatosensory cortex re-form specific callosal projections. Exp Neurol. 139, (1996), 131-42.

Hiromatsu Y, Yang D, Bednarczuk T, et al. Cytokine profiles in eye muscle tissue and orbital fat tissue from patients with thyroid-associated ophthalmopathy. J Clin Endocrinol Metab, Vol. 85, (2000), pp.1194-1199.

Hoyt WF, Frisen L, Newman NM. Fundoscopy of nerve fiber layer defects in glaucoma. Invest Ophthalmol. 12, (1973), 814-29.

Humphrey CD, Kreit JD. Nerve repair and cable grafting for facial paralysis.FPS, Vol. 24, (2008),pp.170-176.

Inatomi T, Nakamura T, Koizumi N. Midterm results on ocular surface reconstruction using cultivated autologous oral mucosal epithelial transplantation. Am J Ophthalmol, Vol. 141, (2006), pp. 267-275.

Inoue $\mathrm{Y}$, Iriyama A, Ueno S, et al. Subretinal transplantation of bone marrow mesenchymal stem cells delays retinal degeneration in the rcs rat model of retinal degeneration. Exp Eye Res. 85, (2007), 234-41.

Iwata F, Patronas NJ, Caruso RC, et al. Association of visual field, cup-disc ratio, and magnetic resonance imaging of optic chiasm. Arch Ophthalmol. 115, (1997), 729-32.

Iwata K, Kurosawa A, Sawaguchi S. Wedge-shaped retinal nerve fiber layer defects in experimental glaucoma preliminary report. Graefes Arch Clin Exp Ophthalmol. 223, (1985), 184-9. 
Johnson EC, Deppmeier LMH, Wentzien SKF, et al. Chronology of optic nerve head and retinal responses to elevated intraocular pressure. Invest Ophthalmol Vis Sci. 41, (2000), 431-442.

Johnson MW, Kincaid MC, Trobe JD. Bilateral retrobulbar optic nerve infarctions after blood loss and hypotension. A clinicopathologic case study. Ophthalmology. 94, (1987), 1577-84.

Johnson TV, Bull ND, Hunt DP, et al. Neuroprotective effects of intravitreal mesenchymal stem cell transplantation in experimental glaucoma. Invest Ophthalmol Vis Sci. 51, (2010), 2051-9.

Johnston MC, Noden DM, Hazelton RD et al. Origins of avian ocular and periocular tissues. Exp Eye Res 1979; 29: 27-43.

Kahaly J, Forster G, Hansen C. Glycosaminoglycans in thyroid eye disease. Thyroid, Vol.8, (1998), pp.429-432.

Kelley MJ, Rose AY, Keller KE, et al. Stem cells in the trabecular meshwork: Present and future promises. Exp Eye Res. 88, (2009), 747-51.

Kenyon KR, Tseng SC. Limbal autograft transplantation for ocular surface disorders. Ophthalmology, Vol.96, (1989), pp.709-722.

Kerrigan LA, Zack DJ, Quigley HA, et al. Tunel-positive ganglion cells in human primary open-angle glaucoma. Arch Ophthalmol. 115, (1997), 1031-5.

Klein R, Chou CF, Klein BE, et al. Prevalence of age-related macular degeneration in the us population. Arch Ophthalmol. 129, (2011), 75-80.

Korn B, Kikkawa D, Hicok K. Identification and characterization of adult stem cells from human orbital adipose tissue. Ophthal Plast Reconstr Surg, Vol. 25, No. 1, (2009), pp. 27- 32.

Ko S, Nauta A, Wong V. The role of stem cells in cutaneous wound healing: what do we really know? Plast Reconstr Surg, Vol. 127, (2011), pp.10S-20S.

Krulova M, Pokorna K, Lencova A et al. A Rapid Separation of Two Distinct Populations of Mouse Corneal Epithelial Cells with Limbal Stem Cell Characteristics by Centrifugation on Percoll Gradient. Invest Ophthalmol Vis Sci, Vol. 49, (2008), pp. 3903-3908.

Kumar S, Coenen M, Scherer P et al. Evidence for enhanced adipogenesis in the orbits of patients with graves ophthalmopathy. Journ Clinic Endocrin Metab, Vol.89, (2003), pp.930-935.

Lamba DA, Gust J, Reh TA. Transplantation of human embryonic stem cell-derived photoreceptors restores some visual function in crx-deficient mice. Cell Stem Cell. 4, (2009a), 73-9.

Lamba DA, Karl MO, Reh TA. Strategies for retinal repair: Cell replacement and regeneration. Prog Brain Res. 175, (2009b), 23-31.

Laouri M, Chen E, Looman M, Gallagher M. The burden of disease of retinal vein occlusion: Review of the literature. Eye (Lond), (2011).

Lau K, Paus R, Tiede $S$ et al. Exploring the role of stem cells in cutaneous wound healing. Experimental Dermatology, Vol. 18, (2009), pp.921-933. 
Lee EY, Xia Y, Kim WS et al. Hypoxia-enhanced wound healing function of adipose-derived stem cells: Increase in stem cell proliferation and up-regulation of VEGF and bFGF. Wound Repair Regen, Vol.17, (2009), pp.540-547.

Li D, Tseng S. Differential regulation of keratinocyte growth factor and hepatocyte growth factor/scatter factor by different cytokines in human corneal and limbal fibroblasts. J. Cell. Physiol, Vol. 172, (1997), pp.361-72.

Li N, Li XR, Yuan JQ. Effects of bone-marrow mesenchymal stem cells transplanted into vitreous cavity of rat injured by ischemia/reperfusion. Graefes Arch Clin Exp Ophthalmol. 247, (2009), 503-14.

Li W, Sun X, Wang Z et al. The effect of nerve growth factor on differentiation of corneal limbal epithelial cells to conjunctival goblet cells in vitro. Mol Vis, Vol. 16, (2010 Dec 15), pp.2739-2744.

Liu K, Tedeschi A, Park KK, He Z. Neuronal intrinsic mechanisms of axon regeneration. Annu Rev Neurosci. 34, (2011), 131-52.

Lu B, Malcuit C, Wang S, et al. Long-term safety and function of rpe from human embryonic stem cells in preclinical models of macular degeneration. Stem Cells. 27, (2009), 2126-35.

Lund RD, Wang S, Klimanskaya I, et al. Human embryonic stem cell-derived cells rescue visual function in dystrophic rcs rats. Cloning Stem Cells. 8, (2006), 189-99.

MacFadyen DJ, Drance SM, Douglas GR, et al. The retinal nerve fiber layer, neuroretinal rim area, and visual evoked potentials in ms. Neurology. 38, (1988), 1353-8.

MacLaren RE, Pearson RA, MacNeil A, et al. Retinal repair by transplantation of photoreceptor precursors. Nature. 444, (2006), 203-7.

Majo F, Rochat A, Nicolas M et al. Location of corneal epithelial stem cells. Nature, Vol 463, (2010), pp. E10.

Mangat HS. Retinal artery occlusion. Surv Ophthalmol. 40, (1995), 145-56.

Maniscalco JE, Habal MB. Microanatomy of the optic canal. J Neurosurg. 48, (1978), 402-6.

Meller D, Pires RT, Tseng SC. Ex vivo preservation and expansion of human limbal epithelial stem cells on amniotic membrane cultures. Br J Ophthalmol, Vol. 86; (2002), pp. 463-471.

Meller D, Tseng S. Conjunctival epithelial cell differentiation on amniotic membrane. Invest Ophthalmol Vis Sci, Vol. 40, (1999), pp. 878-86.

Meltzer N, Alam D. Facial paralysis rehabilitation: state of the art. Curr Opin Otolaryngol Head Neck Surg, Vol. 18, (2010), pp.232-7.

Millesi H, Meissl G, Berger A. The interfascicular nerve-grafting of the median and ulnar nerves. J Bone Joint Surg Am, Vol. 54, No. 4, (1972 Jun), pp.727-750.

Minckler DS. Histology of optic nerve damage in ocular hypertension and early glaucoma. Surv Ophthalmol. 33 Suppl, (1989), 401-11.

Minckler DS, Bunt AH, Johanson GW. Orthograde and retrograde axoplasmic transport during acute ocular hypertension in the monkey. Invest Ophthalmol Vis Sci. 16, (1977), 426-41.

Miri A, Mathew M, Dua HS. Quality of life after limbal transplants. Ophthalmology, Vol.117, No. 3, (2010), pp.638, 638.e1-3. 
Miri A, Al-Deiri B, Dua HS. Long-term outcomes of Autolimbal and Allolimbal transplants. Ophthalmology, Vol. 117, No. 6, (2010), pp.1207-1213.

Mitchell P. A systematic review of the efficacy and safety outcomes of anti-vegf agents used for treating neovascular age-related macular degeneration: Comparison of ranibizumab and bevacizumab. Curr Med Res Opin. 27, (2011), 1465-75.

Moore DL, Goldberg JL. Four steps to optic nerve regeneration. J Neuroophthalmol. 30, (2011), 347-60.

Moore J, Mcmullen C, Mahon G et al. The Corneal Epithelial Stem Cell. DNA And Cell Biology, Vol. 21, (2002), pp. 443-51.

Morrison JC, Johnson EC, Cepurna W, Jia L. Understanding mechanisms of pressureinduced optic nerve damage. Prog Retin Eye Res. 24, (2005), 217-40.

$\mathrm{Mu} \mathrm{X}, \mathrm{Fu} \mathrm{X}$, Sun $\mathrm{H}$, et al. A gene network downstream of transcription factor math5 regulates retinal progenitor cell competence and ganglion cell fate. Dev Biol. 280, (2005), 467-81.

Neufeld AH. Nitric oxide: A potential mediator of retinal ganglion cell damage in glaucoma. Surv Ophthalmol. 43 Suppl 1, (1999), S129-35.

Neufeld AH, Hernandez MR, Gonzalez M. Nitric oxide synthase in the human glaucomatous optic nerve head. Arch Ophthalmol. 115, (1997), 497-503.

Nowak JA, Polak L, Pasolli HA et al. Hair follicle stem cells are specified and function in early skin morphogenesis. Cell Stem Cell, Vol. 3, (2008), pp.33-43.

Okisaka S, Murakami A, Mizukawa A, Ito J. Apoptosis in retinal ganglion cell decrease in human glaucomatous eyes. Jpn J Ophthalmol. 41, (1997), 84-8.

Optic Neuritis Study Group. The 5-year risk of ms after optic neuritis. Experience of the optic neuritis treatment trial. Neurology. 49, (1997), 1404-13.

Park BC, Shen X, Samaraweera M, Yue BY. Studies of optineurin, a glaucoma gene: Golgi fragmentation and cell death from overexpression of wild-type and mutant optineurin in two ocular cell types. Am J Pathol. 169, (2006), 1976-89.

Pease ME, McKinnon SJ, Quigley HA, et al. Obstructed axonal transport of bdnf and its receptor trkb in experimental glaucoma. Invest Ophthalmol Vis Sci. 41, (2000), 764774 .

Pellegrini G, Dellambra E, Golisano O, et al. p63 identifies keratinocyte stem cells. Proc Natl Acad Sci U S A., Vol.98, (2001), pp. 3156-3161.

Pellegrini G. Golisano O, Paterna P, et al. Location and clonal analysis of stem cells and their differentiated progeny in the human ocular surface. J Cell Biol, Vol. 145, (1999), pp.769-82.

Pellegrini G, Traverso C, Franzi A et al. Long-term restoration of damaged corneal surfaces with autologous cultivated corneal epithelium. Lancet, Vol. 349, (1997), pp. 990-993.

Pels E, van der Gaag R. HLA-A,B,C, and HLA-DR antigens and dendritic cells in fresh and organ preserved corneas. Cornea, Vol. 3, (1984), pp.231-239.

Perry VH, Anthony DC. Axon damage and repair in multiple sclerosis. Philos Trans $R$ Soc Lond B Biol Sci.354, (1999), 1641-7. 
Pluchino S, Zanotti L, Rossi B, et al. Neurosphere-derived multipotent precursors promote neuroprotection by an immunomodulatory mechanism. Nature. 436, (2005), 266-71.

Qi hong, Zheng Xiaofen, Yuan Xioyong et al. Potential localization of putative stem/progenitor cells in human bulbar conjunctival epithelium. J Cell Physiol, Vol. 225, (2010), pp.180-185.

Quigley HA. Ganglion cell death in glaucoma: Pathology recapitulates ontogeny. Aust N Z J Ophthalmol. 23, (1995), 85-91.

Quigley HA, Addicks EM. Chronic experimental glaucoma in primates. Ii. Effect of extended intraocular pressure elevation on optic nerve head and axonal transport. Invest Ophthalmol Vis Sci. 19, (1980), 137-52.

Quigley HA, Addicks EM, Green WR, Maumenee AE. Optic nerve damage in human glaucoma. Ii. The site of injury and susceptibility to damage. Arch Ophthalmol. 99, (1981), 635-49.

Quigley HA, Broman AT. The number of people with glaucoma worldwide in 2010 and 2020. Br J Ophthalmol. 90, (2006), 262-7.

Quigley HA, Dunkelberger GR, Green WR. Retinal ganglion cell atrophy correlated with automated perimetry in human eyes with glaucoma. Am J Ophthalmol. 107, (1989), 453-64.

Quigley HA, Guy J, Anderson DR. Blockade of rapid axonal transport. Effect of intraocular pressure elevation in primate optic nerve. Arch Ophthalmol. 97, (1979), 525-31.

Quigley HA, McKinnon SJ, Zack DJ, et al. Retrograde axonal transport of bdnf in retinal ganglion cells is blocked by acute iop elevation in rats. Invest Ophthalmol Vis Sci. 41, (2000), 3460-6.

Quigley HA, Miller NR, George T. Clinical evaluation of nerve fiber layer atrophy as an indicator of glaucomatous optic nerve damage. Arch Ophthalmol. 98, (1980), 1564-71.

Quigley HA, Nickells RW, Kerrigan LA, et al. Retinal ganglion cell death in experimental glaucoma and after axotomy occurs by apoptosis. Invest Ophthalmol Vis Sci. 36, (1995), 774-86.

Radius RL. Pressure-induced fast axonal transport abnormalities and the anatomy at the lamina cribrosa in primate eyes. Invest Ophthalmol Vis Sci. 24, (1983), 343.

Rezaie T, Child A, Hitchings R, et al. Adult-onset primary open-angle glaucoma caused by mutations in optineurin. Science. 295, (2002), 1077-9.

Ren H, Cao Y, Zhao Q et al. Proliferation and differentiation of bone marrow stromal cells under hypoxic conditions. Biochem Biophys Res Commun,Vol. 347, (2006), pp.12-21.

Rizzo JFd, Lessell S. Risk of developing multiple sclerosis after uncomplicated optic neuritis: A long-term prospective study. Neurology. 38, (1988), 185-90.

Ropper AH, Samuels MA. (2009). Bell's palsy section of Diseases of the cranial nerves, In Adams and Victor's Principles of Neurology, (9th ed.), pp. 1330-1331. New York: McGraw-Hill. 
Sahel J, Bonnel S, Mrejen S, Paques M. Retinitis pigmentosa and other dystrophies. Dev Ophthalmol. 47, 160-7.

Salvi M, Vannucchi G, Campi I. Efficacy of rituximab treatment for thyroid-associated ophthalmopathy as a result of intraorbital B-cell depletion in one patient unresponsive to steroid immunosuppression. Eur Journ Endocrinol, Vol. 154, (2006 Apr), pp. 511-7.

Sasaki M, Abe R. Fujita Y et al. Mesenchymal stem cells are recruited into wounded skin and contribute to wound repair by transdifferentiation into multiple skin cell type. $J$ Immunol, Vol.180, (2008), pp. 2581-2587.

Schofield R. The stem cell system. Biomed Pharmacother, Vol. 37, (1983), pp. 375-380.

Schrader S, Notara M, Beaconsfield $M$ et al. Tissue engineering for conjunctival reconstruction: established methods and future outlooks. Current Eye Res, Vol. 34, No. 11, (2009), pp. 913-24.

Schrader S, Notara M, Tuft S et al. Simulation of an in vitro niche environment that preserves conjunctival progenitor cells. Regen Med, Vol. 5, No. 6, (2010 Nov), pp. 877-889.

Schurr MJ, Foster KN, Centanni JM et al. Phase I/II clinical evaluation of Stratagraft: A consistent, pathogen-free human skin substitute. J Trauma, Vol. 66, (2009), pp. 866873,4 .

Shortt AJ, Secker GA, Lomas RJ et al. The effect of amniotic membrane preparation method on its ability to serve as a substrate for the ex-vivo expansion of limbal epithelial cells. Biomaterials, Vol. 30, (2009), pp. 1056-1065.

Sieving PA, Caruso RC, Tao W, et al. Ciliary neurotrophic factor (cntf) for human retinal degeneration: Phase i trial of cntf delivered by encapsulated cell intraocular implants. Proc Natl Acad Sci U S A. 103, (2006), 3896-901.

Simonelli F, Maguire AM, Testa F, et al. Gene therapy for leber's congenital amaurosis is safe and effective through 1.5 years after vector administration. Mol Ther. 18, (2009), 64350.

Singhal S, Lawrence JM, Salt TE, et al. Triamcinolone attenuates macrophage/microglia accumulation associated with nmda-induced rgc death and facilitates survival of muller stem cell grafts. Exp Eye Res. 90, 308-15.

Sohur US, Emsley JG, Mitchell BD, Macklis JD. Adult neurogenesis and cellular brain repair with neural progenitors, precursors and stem cells. Philos Trans $R$ Soc Lond B Biol Sci. 361, (2006), 1477-97.

Sorisky A. From preadipocyte to adipocyte: differentiation-directed signals of insulin from the cell surface to the nucleus. Crit Rev Clin Lab Sci, Vol.36, (1999), pp.1-34

Stroman GA, Stewart WC, Golnik KC, et al. Magnetic resonance imaging in patients with low-tension glaucoma. Arch Ophthalmol. 113, (1995), 168-72.

Tao W, Wen R, Goddard MB, et al. Encapsulated cell-based delivery of cntf reduces photoreceptor degeneration in animal models of retinitis pigmentosa. Invest Ophthalmol Vis Sci. 43, (2002), 3292-8.

Trapp BD, Peterson J, Ransohoff RM, et al. Axonal transection in the lesions of multiple sclerosis. N Engl J Med. 338, (1998), 278-85. 
Tropepe V, Coles BL, Chiasson BJ, et al. Retinal stem cells in the adult mammalian eye. Science. 287, (2000), 2032-6.

Tsai RJ, Ho YS, Chen J. The effects of fibroblasts on the growth and differentiation of human bulbar conjunctival epithelial cells in an in vitro conjunctival equivalent. Invest Ophthalmol Vis Sci, Vol. 35, (1994), pp. 2865-2875.

Tsai RJ, Tsai RY. Ex vivo expansion of corneal stem cells on amniotic membrane and their outcome. Eye and Contact Lens, Vol. 36, No. 5, (2010), pp. 305-309.

Tsai R, Tseng S. Substrate modulation of cultured rabbit conjunctival epithelial cell differentiation and morphology. Invest Ophthalmol Vis Sci, Vol. 10, (1988 Oct), pp.1565-1576.

Tsai R, Tseng S. Effect of stromal inflammation on the outcome of limbal transplantation for corneal surface reconstruction. Cornea, Vol. 14, (1995), pp. 439-449.

Tseng SC, Prabhasawat P, Barton K, et al. Amniotic membrane transplantation with or without limbal allografts for corneal surface reconstruction in patients with limbal stem cell corneal epithelium deficiency. Arch Ophthalmol, Vol. 116, (1998), pp.431441.

Umemoto T, Yamato M, Nishida K, et al. Rat limbal epithelial side population cells exhibit a distinct expression of stem cell markers that are lacking in side population cells from the central cornea. FEBS Lett, Vol. 579; (2005), pp. 6559-6574.

Valyasevi R, Harteneck D, Dutton C and Bahn R. Stimulation of adipogenesis, peroxisome proliferator-activated receptor-y (ppary) and thryotropin receptor by ppary agonist in human orbital preadipocyte fibroblasts. J Clin Endocrinol Metab, Vol. 87, (1992), pp. 2353-2358.

Vickers JC, Hof PR, Schumer RA, et al. Magnocellular and parvocellular visual pathways are both affected in a macaque monkey model of glaucoma. Aust N Z J Ophthalmol. 25, (1997), 239-43.

Walsh S, Midha R. Use of Stem Cells to Augment Nerve Injury Repair. Neurosurgery, Vol. 65, (2009), pp. A80-A86.

Wang C, Jacob B, Nah G et al. Runx family genes, niche, and stem cell quiescence. Blood Cells, Molecules, and Diseases, Vol. 44, (2010), pp. 275-286.

Wang SW, Kim BS, Ding K, et al. Requirement for math5 in the development of retinal ganglion cells. Genes Dev. 15, (2001), 24-9.

Wang SW, Mu X, Bowers WJ, et al. Brn3b/brn3c double knockout mice reveal an unsuspected role for brn3c in retinal ganglion cell axon outgrowth. Development. 129, (2002), 467-77.

Watanabe K, Nishida K, Yamato M et al. Human limbal epithelium contains side population cells expressing the ATP-binding cassette transporter ABCG2. FEBS Letters, Vol. 565, (2004), pp. 6-10.

Weber AJ, Chen H, Hubbard WC, Kaufman PL. Experimental glaucoma and cell size, density, and number in the primate lateral geniculate nucleus. Invest Ophthalmol Vis Sci. 41, (2000), 1370-9.

Wei ZG, Cotsarelis G, Sun TT et al. Label-retaining cells are preferentially located in forniceal epithelium: Implications on conjunctival epithelial homeostasis. Invest Ophthalmol Vis Sci, Vol. 36, (1995), pp.236-246. 
West EL, Pearson RA, Tschernutter M, et al. Pharmacological disruption of the outer limiting membrane leads to increased retinal integration of transplanted photoreceptor precursors. Exp Eye Res. 86, (2008), 601-11.

Wester ST, Lee WW, Shi W. Eyelash growth from application of bimatoprost in gel suspension to the base of the eyelashes. Ophthalmology.Vol.117, No. 5, (2010 May), pp. 1024-1031.

Whitmore AV, Libby RT, John SW. Glaucoma: Thinking in new ways-a role for autonomous axonal self-destruction and other compartmentalised processes? Prog Retin Eye Res. 24, (2005), 639-62.

Wilson S, He Y, Zieske J, et al. Effect of epidermal growth factor, hepatocyte growth factor, and keratinocyte growth factor, on proliferation, motility and differentiation of human corneal epithelial cells. Exp. Eye Res. Vol. 59, (1994), pp. 665-678.

Wirstschafter JD, Ketcham JM, Weinstock RJ et al. Mucocutaneous junction as the major source of replacement palpebral conjunctival epithelial cells. Invest Ophthalmol Vis Sci, Vol. 40, (1999), pp.3138-3146.

Wolff E. The anatomy of the eye and orbit. Philadelphia: Blakiston, 1948.

Won $\mathrm{CH}$, Yoo HG, Kwon OS. Hair growth promoting effects of adipose tissue-derived stem cells. J Dermatol Sci. Vol. 57, No. 2, (2010), pp. 134-137.

Wong TY, Chakravarthy U, Klein R, et al. The natural history and prognosis of neovascular age-related macular degeneration: A systematic review of the literature and metaanalysis. Ophthalmology. 115, (2008), 116-26.

Wu Y, Chen L, Scott PG, Tredgett EE. Stem Cells, Vol. 25, (2007), pp. 2648-2659.

WuDunn D. Mechanobiology of trabecular meshwork cells. Exp Eye Res. 88, (2009), 71823.

Yamagami S, Yokoo S, Mimura T et al. Distribution of Precursors in Human Corneal Stromal Cells and Endothelial Cells. Ophthalmology, Vol.114, No. 3 (2007 Mar), pp. 433-439

Yu S, Tanabe T, Dezawa M, et al. Effects of bone marrow stromal cell injection in an experimental glaucoma model. Biochem Biophys Res Commun. 344, (2006), 10719.

Yücel YH, Zhang Q, Gupta N, et al. Loss of neurons in magnocellular and parvocellular layers of the lateral geniculate nucleus in glaucoma. Arch Ophthalmol. 118, (2000), 378-84.

Zajicova A, Pokorna K, Lencova A et al. Treatment of Ocular Surface Injuries by Limbal and Mesenchymal Stem Cells Growing on Nanofiber Scaffolds. Cell Transplantation, Volume 19, Number 10, (2010) , pp. 1281-1290.

Zavan B, Michelotto L, Lancerotto L et al. Neural potential of a stem cell population in the adipose and cutaneous tissues. Neurological Research, Vol. 32, No. 1, (2010), pp. 4754.

Zhang K, Hopkins JJ, Heier JS, et al. Ciliary neurotrophic factor delivered by encapsulated cell intraocular implants for treatment of geographic atrophy in age-related macular degeneration. Proc Natl Acad Sci U S A. 108, (2011), 6241-5. 
Zhang Y, Klassen HJ, Tucker BA, et al. Cns progenitor cells promote a permissive environment for neurite outgrowth via a matrix metalloproteinase-2-dependent mechanism. J Neurosci. 27, (2007), 4499-506.

Zuk P, Zhu M, Ashjian P et al. Human Adipose Tissue Is a Source of Multipotent Stem Cells. Molecular Biology of the Cell, Vol. 13, (2002), pp. 4279-4295. 


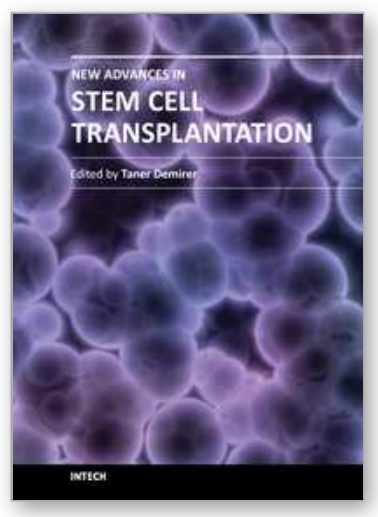

\author{
New Advances in Stem Cell Transplantation \\ Edited by Prof. Taner Demirer
}

ISBN 978-953-51-0013-3

Hard cover, 582 pages

Publisher InTech

Published online 24, February, 2012

Published in print edition February, 2012

This book documents the increased number of stem cell-related research, clinical applications, and views for the future. The book covers a wide range of issues in cell-based therapy and regenerative medicine, and includes clinical and preclinical chapters from the respected authors involved with stem cell studies and research from around the world. It complements and extends the basics of stem cell physiology, hematopoietic stem cells, issues related to clinical problems, tissue typing, cryopreservation, dendritic cells, mesenchymal cells, neuroscience, endovascular cells and other tissues. In addition, tissue engineering that employs novel methods with stem cells is explored. Clearly, the continued use of biomedical engineering will depend heavily on stem cells, and this book is well positioned to provide comprehensive coverage of these developments.

\title{
How to reference
}

In order to correctly reference this scholarly work, feel free to copy and paste the following:

Sara T. Wester and Jeffrey Goldberg (2012). Stem Cells in Ophthalmology, New Advances in Stem Cell Transplantation, Prof. Taner Demirer (Ed.), ISBN: 978-953-51-0013-3, InTech, Available from: http://www.intechopen.com/books/new-advances-in-stem-cell-transplantation/stems-cells-in-ophtamology

\section{INTECH}

open science | open minds

\section{InTech Europe}

University Campus STeP Ri Slavka Krautzeka 83/A 51000 Rijeka, Croatia Phone: +385 (51) 770447

Fax: +385 (51) 686166 www.intechopen.com

\section{InTech China}

Unit 405, Office Block, Hotel Equatorial Shanghai No.65, Yan An Road (West), Shanghai, 200040, China 中国上海市延安西路65号上海国际贵都大饭店办公楼 405 单元 Phone: +86-21-62489820

Fax: $+86-21-62489821$ 
(C) 2012 The Author(s). Licensee IntechOpen. This is an open access article distributed under the terms of the Creative Commons Attribution 3.0 License, which permits unrestricted use, distribution, and reproduction in any medium, provided the original work is properly cited. 